\title{
Sosyal Pazarlamada Kullanilan Teori ve Modeller
}

\author{
Theories and Models Used in Social Marketing
}

Tolga ŞENTÜRK *

\begin{abstract}
$\ddot{O} Z$
Teoriler, olgu ve olayların karmaşılklkklarını insan kavrayışı için çözen ve basitleştiren, birbiriyle ilişkili bir dizi kavram, tanım ve önermelerdir. Modeller ise, olgu ve kavramların anlaşılabilir formalarını oluşturan, vakaları görselleştiren, bilimsel olgulara izahlar getiren şekiller ve önermeler olarak tanımlamaktadır (Coll, 2006). Son yirmi yıldir sosyal pazarlamada teori ve model kullanımı çokça tartışlmakta, araştırmacılar ve uygulamacılar teori ve model kullanımına önem göstermeye davet edilmektedir. Bununla birlikte yapılan araştırmalar pek çok sosyal pazarlamacının teori ve model ayrımın yapamadı̆̆ını, hangi sosyal müdahale için hangi teori ve modellerin kullanıldığı konusunda bilgi sahibi olmadığını, sosyal müdahalelerin betimleyici araştırma, uygulama ve değerlendirme süreçlerinde teori ve modellerden nasil yararlanabilecekleri hakkında her hangi bir fikir sahibi olmadiğını ortaya koymaktadır. Söz konusu eksikliklerin giderilmesine akademik katkı sunmak adına çalışmada teori ve model kullanımının önemi, sosyal pazarlamada kullanılan teori ve modllerin neler olduğu ve nasıl kullanıldığı ele alınmıştır. Yapılan literatür araştırması çerçevesinde sosyal pazarlama müdahalelerinde en çok kullanilan teori ve modeller bir araya getirilmiş ve örnek uygulamalarla açılklanmıştır. Yine bu teori ve modellerin sosyal müdahalenin hangi aşamalarında kullanılabileceği aktarılmış, verilen bilgiler tablo aracıllğılyla özetlenerek araştırmacıların istifadesine sunulmuştır.
\end{abstract}

\author{
ANAHTAR KELIMELER \\ Sosyal Pazarlama, Sosyal Pazarlama Karması, Davranış Değişimi
}

\begin{abstract}
Theories are a set of interrelated concepts, definitions and propositions that solve and simplify the complexities of phenomena and events for human comprehension. Models, on the other hand, are defined as figures and propositions that create understandable forms of facts and concepts, visualize cases, and provide explanations to scientific facts (Coll, 2006). In the last two decades, the use of theory and model in social marketing has been widely discussed, and researchers and practitioners are invited to pay attention to the use of theory and model. However, studies have revealed that many social marketers are unable to distinguish between theories and models, they do not have information about which theories and models are used for certain social intervention, and they do not have any idea about how social interventions can benefit from theories and models in descriptive research, implementation and evaluation processes. In order to make an academic contribution to the aforementioned deficiencies, the importance of the use of theory and model, what are the theories and models used in social marketing and how they are used are discussed in the study. Within the framework of the literature research, the most used theories and models in social marketing interventions were brought together and explained with sample interventions. The stages of social intervention where these theories and models can be used were also conveyed, and the information provided was summarized through a table and presented to the use of researchers.
\end{abstract}

KEYWORDS

Social Marketing, Social Marketing Mix, Behavior Change

\begin{tabular}{|c|c|c|}
\hline \multicolumn{2}{|r|}{$\begin{array}{l}\text { Makale Geliş Tarihi / Submission Date } \\
26.08 .2020\end{array}$} & $\begin{array}{c}\text { Makale Kabul Tarihi / Date of Acceptance } \\
14.10 .2020\end{array}$ \\
\hline Atıf & $\begin{array}{l}\text { Şentürk, T. (2020). Sosyal Pazarlamad } \\
\text { Yüksekokulu Dergisi, } 23 \text { (2), 603-621. }\end{array}$ & Modeller. Selçuk Üniversitesi Sosyal Bilimler Meslek \\
\hline
\end{tabular}

\footnotetext{
* Dr. Öğr. Üyesi, İzmir Kâtip Çelebi Üniversitesi, Medya ve İletişim Bölümü, tolga.senturk @ikc.edu.tr, ORCID: 0000-0002-9103-3048
} 


\section{GİRIŞ}

Sosyal pazarlama son yıllarda bir disiplin olarak kendini geliştirmekle kalmamış, olumlu sosyal değişim yaratmakla ün kazanan dinamik bir disiplin haline gelmiştir. Bunun yanında sosyal pazarlama, konvansiyonel pazarlamanın sonuç odaklı pratiğini kullanmakta, olumlu davranış değişimlerinin ötesine geçerek araştırmaya dayalı, somut ve değerlendirilebilir sonuçların nasıl oluşturulacağı konusunda farkındalığın artırılmasına yardımcı olmaktadır (McKie ve Toledano, 2008).

Sosyal pazarlama büyük oranda sivil toplum kuruluşlarının sosyal sorumluluk faaliyetlerinde, yerel ve ulusal kamu otoritelerinin yürüttügü kampanyalarda kendini göstermektedir. Sosyal pazarlamacılar da bu sektörlerle çalışmaya eğilimlidir. Onların öncelikli hedefi çevre kirliliğinin, önlenebilir hastalıkların, alkolizmin, bağımlılığın ve intiharların azaltılması gibi sosyal açıdan arzu edilir sonuçlara ulaşmaktır (Buyucek vd., 2016). Belirli sorunları etkili bir şekilde çözmek için sosyal pazarlamacılar, örneğin Sağlık Bakanlığı gibi kurumlarda kampanyalarını tıbbi bilgiler, birincil ve ikincil araştırmalar üzerine kurgular. Burada başarı kıstası kurumsal satışların ya da itibarın artması değil, hedeflenen olumsuz sağlık vakalarının azaltılmasıdır. Bu tip bir anlayış toplumlar için çok büyük bir fayda potansiyeli doğurmaktadır. Zira ABD'de yapılan araştırmaların da gösterdiği üzere obeziteden kayaklı ölümler (Kotler vd., 2010) ile prematüre bebek ölümlerinin \%50'sinden fazlası hatalı ve önlebilir hayat tazlarından, yani hatalı davranışlardan kaynaklanmaktadır (Hastings ve Saren, 2003). Dahası adli vakalar, ırkçılık, cinsiyet ayrımcılığı gibi sosyal sorunlar da insanoğlunun davranış problemleri olarak görülebilir. Sosyal pazarlamacılar burada ortaya çıkan sorunları firsat bilerek bir teori ya da teknoloji transfer ofisi gibi hareket ederler (Hastings ve Saren, 2003). Bu çerçevede tütün sektörünün sigara satmakta kullandığı stratejiler ve teknikler insanlara daha sağlıklı yaşam tarzlarının benimsetilmesi için kullanılır. İşte burada sosyal pazarlama kamu otoritelerine, sivil topluma ve sağlık kuruluşlarına teori ve yöntem çerçevesinde önemli katkılar sunabilmekte, bilgi ve tecrübe transfer edebilmektedir.

Sosyal pazarlamanın uygulama sahası genişledikçe teori kullanımının önemi artmaktadır (Andreasen, 1997). Lefebvre (2000) çoğu sosyal pazarlama müdahalesinin ya da planlamasının teorik bir çerçeveden yoksun olduğunu belirtmektedir. Yapılan araştırmalar bir çok sosyal pazarlamacının teori ve modelin gerçekte ne olduğunu, ne işe yaradığını ve ne zaman kullanıldığını bilmediğini (Walsh vd., 1993; Lefebvre, 2000); yine sosyal pazarlamacıların bir çoğunun hangi sosyal müdahalelerde hangi teorilerin ya da modellerin kullanıldığ hakkında bilgi sahibi olmadığını ortaya koymaktadır (Andreasen, 2006; Luca ve Suggs, 2013). Önceki çalışmalarda tespit edilen bulgular çerçevesinde bu araştırmanın amacı, sosyal pazarlama çalışmalarında teori ve model kullanımının önemini, kullanılan teori ve modellerin neler olduğunu ve bunların hangi sosyal müdahale tasarımlarına katkı sağladığını ortaya koymak, bu sayede alandaki araştırmacılara ve uygulamacılara rehberlik etmektir. Çalışma kapsamında yürütülen literatür taraması çerçevesinde öncelikle sosyal pazarlamanın tanımı ve tarihsel gelişimi aktarılmıştır. Daha sonra teori ve model kavramlarının ne olduğu ve sosyal pazarlama çalışmalarında teori ve model kullanımının önemi, araştırmacılara ve uygulamacılara sağladığı faydalar çerçevesinde ortaya konmuştur. Çalışmanın son kısmında ise, sosyal mühadalelerde bugüne kadar kullanılan teorilerin neler olduğu ve nasıl kullanıdığı açıklanmış, ortaya konan bilgiler tablo aracıyla özetlenmiştir.

\section{SOSYAL PAZARLAMA: TANIM VE TARIHSEL GELIŞSIM}

Sosyal pazarlamanın öncülerinden olan Philip Kotler, Zaltman ile yayınladığı (1971) makalesinde "sosyal pazarlama" teriminin ilk kullanımını ve tanımını (s. 5) şu şekilde yapmıştır:

"Sosyal fikirlerin kabul edilebilirliğine etki etmeyi hedefleyen ve bunu yaparken ürün, fiyatlandirma, iletişim, dağıtım ve pazar araştırmasını da göz önünde bulunduran programların tasarımı, uygulanması ve kontrolü."

Her ne kadar alanın öncülerinde de olsalar, Kotler ve Zaltman'ın (1971) ortaya koyduğu fikirler pazarlama dünyasından yalıtılmış olarak kabul edilmemelidir. Zira benzer yaklaşımları o dönemde farklı yazarlarda görmek mümkündür. Kotler ve Zaltman, 1960'l1 yıllarda pazarlama pratiğini sosyal sorunlara genişletmekle ilgili çeşitli pazarlama akademisyenlerinin tartışmalarını takiben söz konusu makaleyi yazmıştır (McKie ve Toledano, 2008). Hatta MacFayden vd. (1999; aktaran McKie ve Toledano, 2008), sosyal pazarlama çerçevesinde ele alınabilecek pek çok çalışmanın dünyanın farklı bölgelerinde aynı dönemde ortaya çıtığını belirtmektedir. Yazarların tespitine göre sosyal pazarlamanın ilk örnekleri, hem üçüncü dünya ülkeleri hem de gelişmiş ülkelerindeki uluslararası kalkınma çabalarının bir parçası olarak 1960'lı yıllarda ortaya çıkmıştır.

Sosyal pazarlamanın iki kaynaktan doğduğu söylenebilir. Birincisi, ekonomik fonksiyonları tartışma kabul etmeyen, fakat etik açıdan tartışmaların odağında olan (bkz. Nalbantoğlu, 2018) pazarlamadır. İkincisi ise sağlık ve eğitim hizmetlerinden eşit oranda faydalanmaktan, hukuk önünde eşitliğe kadar uzanan pek çok 
boyutu içeren sosyal adalet kavramıdır. Sosyal pazarlama, ticari pazarlamayı sosyal faydanın gerçekleştirilmesine destek vermek amacıyla uyarlayarak kimliğini geliştirmiştir. İlerleyen yıllardaki tanımlar, konvansiyonel pazarlama teorisinden ve uygulamasından daha geniş unsurları içermeye başlamıştır (McKie ve Toledano, 2008). Kotler ve Roberto (1989:24) sosyal pazarlamanın tanımının, sosyal değişim yönetimi çerçevesinde bir veya birden çok hedef kitleye yönelik programların tasarlanması, uygulanması ve kontrolüne doğru evrildiğini belirtmektedir. Yazarlara göre bu tür toplumsal değişim programları pazar segmentasyonu, tüketici araştırması, ürün konsepti geliştirme ve test, doğrudan iletişim, kolaylaştırma, teşvikler ve hedef kitlenin dahlini en üst düzeye çıkarmak için değişim/mübadele teorisi konseptlerinden faydalanmayı içerir.

Sosyal pazarlama disiplininin önde gelen isimlerinden Alan Andreasen de Kotler ve Zaltman'ın (1971) sosyal pazarlama tanımını güncellemek gerektiğini savunmuştur. Andreasen (1995) sosyal pazarlamayı, hedef kitlelerin ve bireylerin refahı ile içinde yaşadıkları toplumun refahını artırmak adına onların gönüllü davranışlarını etkilemek üzere tasarlanmış programların analizi, planlanması, uygulanması ve değerlendirilmesi için ticari pazarlama tekniklerinin kullanılması şeklinde tanımlamıştır. Andreasen, ticari pazarlama ile sosyal pazarlamanın amaç ve araç çerçevesindeki ayrımını şu şekilde yapmaktadır (1995:8):

1. Sosyal pazarlamanın nihai amacı pazarlamacılara değil, bireylere veya topluma fayda sağlamaktır.

2. Refahı geliştirmenin temel aracı davranışları etkilemektir. Çoğu durumda bu hedef davranışta değiş̧iklik meydana getirmekle gerçekleşir.

3. Hedef kitlenin sosyal pazarlama sürecinde birincil rolü vardır.

Andreasen'in bakış açısına göre, sosyal pazarlama esas olarak kamu otoriteleri ve kar amacı gütmeyen kuruluşlar tarafından gerçekleştirilen, özellikle sağlığın teşviki ve geliştirilmesi ile ilgilenen ve vatandaşların yaşam kalitesini iyileştiren bir alan olarak tanımlanmalıdır. Ticari pazarlamacılardan farklı olarak sosyal pazarlamacılar, belirli bir organizasyonu desteklememekte ve finansal kazançlarını arttırmaya çalışmamaktadır. Bunun yerine, toplumsal olarak bir fayda ortaya çıkarmaya çalışmakta ve insan davranışlarından kaynaklanan sosyal sorunların önlenmesini arzulamaktadır.

Andreasen (1995) gibi Kotler ve Roberto (1989) da sosyal pazarlamanın "sayısız" sosyal sorunun çözümüne olumlu katkıda bulunma potansiyelini ön plana çıkarmıştır. Yazarlara göre sosyal pazarlama, düşük eğitimli ya da eğitimsiz kitleler, uyuşturucu ve alkol kullanımı, genç gebelik, AIDS'in yayılması ve kötü beslenme gibi dünyanın yüzleştiği çeşitli problemlerle mücadeleyi desteklemektedir. Bu sorunlar listesi ve çözüm olarak sosyal pazarlamanın savunuculuğunun yapılması birçok sosyal pazarlama konulu araştırmanın tekrar eden özelliği olarak kaşımıza çıkmaktadır. Araştırmalarda karşılaşılan bu önermeleri genellikle bazı kanıtlanabilir sonuçlar veya çözümler izler. Bu ortak önermelerin sosyal pazarlamaya kuvvetli bir itibar sahibi olmakta yardımcı olduğu görülmektedir. Her ne kadar toplumsal faydaların ön plana çıkartılması araştırma içeriklerinde varlığını sürdürse de, disiplin tartışmalardan uzak kalamamıştır. Örneğin ilerleyen yıllarda Andreasen (2006), Kotler ve Zaltman'ın (1971) sosyal pazarlama tanımının disiplinin "sadece kamu spotu, halkla ilişkiler ya da en basit şekilde sadece eğitim" ile karıştırılmasına sebep olduğunu ileri sürmüştür (s.88). Yazar yöntem, kuram ve uygulamalar arasındaki farklara dikkat çekmiştir. Ayrıca sosyal pazarlama yaklaşımının ticari pazarlama ilkelerini (ör. 4P: Ürün, Fiyat, Dağıtım ve Tutundurma) kullanırken ve ikna edici iletişimi sağlarken olumlu davranış değişimi elde etmek üzere tasarlanması gerektiğini belirtmiştir.

Donovan ve Henley (2003; aktaran McKie ve Toledano, 2008) ise Andreasen'in (1995) sosyal pazarlama tanımında "gönüllü davranış" terimini kullanması ile ilgili önemli bir çekince dile getirmiştir. Yazarlar, sosyal pazarlamacıların amaçlarını gerçekleştirmek için sadece bireysel davranışları etkilemesinin yanı sıra, bireylerin davranışsal değişimini sağlayacak veya önleyebilecek daha büyük yapıları hedeflemesi gerektiği fikrini vurgulamışlardır. Avustralya' daki Ulusal Kalp Vakfı için hazırlanan kamu spotlarında, daha az doymuş yağ tüketmeye ikna olmuş bireylerin kampanyanın nihai hedefi olmasının yanısıra, örneğin bisküvi üreticilerinin de ürünlerinde kullandıkları doymuş yağları çoklu doymamış yağlarla değiştirmeye ikna olmaları çerçevesinde nihai hedefe dâhil edilmeleri gerektiğini savunmuşlardır (Donovan ve Henley,2003; aktaran McKie ve Toledano, 2008). Bu hedef gıda şirketi yöneticileri arasında gönüllü bir davranış değişikliği gerektirirken, doymuş yağ tüketen nihai tüketicilerin davranışlarını da değiştirmeyi içermektedir. Dolayısıyla yazarlar, davranış değişikliği arzu edilen hedef kitlelerin daha geniş bir perspektiften ve dikkatlice seçilmesi gerektiği hususunda önemli bir bakış açısı ortaya koymuştur.

Lefebvre (2000) ise, sosyal pazarlama alanında faaliyet gösteren birçok uzmanın çalışmaları ile ilgili raporlamaları, faaliyetlerden ne gibi çıktılar beklendiğini ve sonuçların nasıl ölçüldüğünü mesleki dergilerde veya konferanslarda dile getirmediklerini belirtmektedir. Yazar ayrıca hedef kitlelerin seçimine ilişkin kararları etkileyen teorik modellerin de birçok uygulamacı ya da araştırmacı tarafından planlama sürecine dâhil edilmediğini vurgulamaktadır. 
Sosyal pazarlama disiplinin meşhur isimlerinlerinden Hastings (2007) de teori kullanımı hususunda Lefebvre'ye (2000) destek veren tespitler ortaya koymaktadır. Yazar, disiplinin davranış değişikliği üzerine odaklanmasının bizi doğal olarak davranış teorisine götürdüğünü dile getirmektedir. McKie ve Toledano (2008), sosyal pazarlamanın halen kendine özgü teorik bir çerçeve oluşturamadığını belirtmektedir. Mevcut teoriler davranış değişimi için ne yapılması gerektiğini bize gösterirken nasıl yapılacağını göstermemektedir (D’Onofrio, 1992). Burada hangi faaliyetin nasıl yapılması gerektiğini ortaya koyacak olan sosyal pazarlamadır (Thackeray and Neiger, 2000). Dolayısıyla sosyal pazarlamacılar için esas olan yeni bir teroik çerçeve üretmek değil, ilgili sosyal müdahaleye uygun teori ya da modelleri seçmek ve kullanmaktır.

\section{SOSYAL PAZARLAMADA TEORİ KULLANIMI}

Teori, olayları veya olguları açıklamak ve tahmin etmek için, değişkenler arasındaki ilişkileri belirleyerek olayların veya olguların sistematik bir görünümünü sunan bir dizi birbiriyle ilişkili kavram, tanım ve önermeler olarak tanımlanmaktadır (Glanz ve Rimer, 1997:11). Green ve arkadaşlarına (1994:398) göre teorinin rolü, olgu ve olayların karmaşıklıklarını insan kavrayışı için çözmek ve basitleştirmektir.

Bilim insanları sebep sonuç ilişkilerini açıklamak için teorilerin yanısıra modellerden de faydalanmaktadır. Coll (2006) modelleri, olgu ve kavramların anlaşılabilir formalarını oluşturan, vakaları görselleştiren, bilimsel olgulara izahlar getiren şekiller ve önermeler olarak tanımlamaktadır. Yazar, kavramsal modellerin deneysel bulgulara ait bilişsel sonuçlar olduğunu ve bu modellerin teorilerden çıkarıldığını aktarmaktadır.

Model terimi ile teori terimi zaman zaman birbirine karıştırılmaktadır. Teoriler tümevarım ya da icat vasıtasıyla olgu ve olayları izah amaciyla oluşturularken, modeller ise teorilerden tümdengelim yolu ile çıkarılır (Collette ve Chiappetta, 1984; aktaran Çelik, 2015). Literatürde aynı olay ya da olguyu izah eden çok sayıda model bulunabilmektedir. Bunun nedeni, aynı olgu ya da olayı açıklayan araştırmacıların farklı fikirler ileri sürmelerinden ve model oluşturmada faydalanabilinecek çok büyük sayıda kaynağın var olmasından ileri gelmektedir (Oh ve Oh, 2011; aktaran Çelik, 2015).

Sosyal pazarlamanın teori ve pratiğinin ilişkisi irdelenirken, sosyal pazarlamanın kendisinin bir teori olmadığını bilerek işe başlamak çok önemlidir. Sosyal pazarlama, birbirinden farklı pek çok teorinin uygulanmasında olanak tanıyan (bkz. Tablo 1) bir disiplindir. Thackeray ve Neiger'e (2000) göre sosyal pazarlama, tüketici değerinin pazarlamacılar tarafından daha iyi anlaşılmasını sağlayan, teoriyi tüketici yönlülük bağlamı içerisinde işleten bir planlama çerçevesidir. Bu sayede pazarlamacılar sosyal pazarlama faaliyetlerini teori ile desteklemenin sinerji yaratan değerini anlamaya daha hazır olurlar. Böylece teori, sosyal pazarlamacılar için dahil edilebilir bir bileşen olarak değil, sosyal pazarlamanın tamamen uygulanabilmesini sağlayan bir araç olarak algılanacaktır (Thackeray ve Neiger, 2000).

Sosyal pazarlama için sunulan teori ve modellerin sayısı çok olsa da, hangi tür sosyal sorunlar için, hangi modelin, hangi durumlarda en uygun olduğuna dair çok az görüş birliği vardır (Hastings, 2007; Lefebvre, 2000; Luca ve Suggs, 2013) . Hatta mevcut olmadığ1 halde "bir sosyal pazarlama teorisine" atıfta bulunan yazarlar da bulunmaktadır (Lefebvre, 2000).

Tablo 1: Sosyal Pazarlamada Kullanılan Teori ve Modeller

\begin{tabular}{|l|r|}
\hline Odak Noktası & Teori ve Modeller \\
\hline Bireysel Teoriler & $\bullet \quad$ Değişim (Mübadele) Teorisi \\
& $\bullet \quad$ Planlı Davranış Teorisi \\
& $\bullet \quad$ Sağlık İnanç Modeli \\
& $\bullet \quad$ Korunmaya Güdülenme Teorisi \\
& $\bullet \quad$ Transteorik Model \\
\hline Bireylerarası Teoriler & $\bullet \quad$ Sosyal Bilişsel Teori \\
\hline Toplumsal Teoriler & $\bullet \quad$ Yeniliklerin Yayılması Teorisi \\
& $\bullet \quad$ Topluluk Örgütleme ve Diğer Katılımcı Modeller \\
& $\bullet \quad$ Medya Çalışmaları Çerçevesi \\
\hline Yönetsel Teoriler & $\bullet \quad$ Sosyo Ekolojik Model \\
\hline
\end{tabular}

Kaynak: Özata ve Kapusuz (2019)'dan geliştirilmiştir

Bazı yazarlar, sosyal pazarlamanın tanımlanmasında değiş̧im (mübadele) kavramının değerini kabul etseler de, sosyal pazarlama programlarının gelişiminde diğer birçok teorik modelin uygulanabileceğini belirtmektedirler (örn. Hastings ve Saren, 2003; Lefebvre ve Rochlin, 1997; Novelli, 1990; Thackeray ve Neiger, 2000). Novelli (1990) pazarlamanın teori tabanlı olduğunu, sosyal ve davranışsal bilimlere dayanan 
tüketici davranışı kuramlarına dayandırıldığını aktarır. Aslında, sosyal pazarlamanın uygulamasında olan da budur (bkz. Thackeray ve Neiger, 2000).

Bununla birlikte Walsh ve arkadaşları (1993), profesyonel sosyal pazarlamacıların mevcut teori kullanımlarında geniş ölçüde ekletik (seçmeci) ve sezgisel olma eğiliminde olduklarını belirtmişlerdir. Dolayısıyla, sosyal pazarlamada kullanılan teori ve modellerin gözden geçirilmesinin araştırmacı ve uygulamacıların öznel seçimlerinin listelenmesi anlamına geldiği söylenebilir. Fakat bu tip incelemeler alanın ilerlemesi açısından faydalı ve önemlidir. Çünkü belirli sosyal müdahaleler için yapılacak doğru teori ve model seçimlerine ön ayak olma potansiyeli taşımaktadır.

Sosyal pazarlamacılar arasında çok azı hedef kitlelerin seçimine, biçimlendirici araştırma çalışmaları sırasında yöneltilen sorulara, seçilen stratejiler konusundaki kararlarını etkileyen teorik modellere, program öğelerinin nasıl seçildiğine ve geliştirildiğine, hangi sonuçların amaçlandığı ve bu sonuçların nasıl ölçüldüğüne odaklanır (Lefebvre, 2000). Dolayısıyla daha profesyonel ve etkili sosyal pazarlama çalışmaları yapabilmek adına planlama, uygulama ve kontrol aşamalarında yol gösterici nitelik taşıyan spesifik teorilerin bilinmesi ve kullanılması büyük önem taşımaktadır. Çalışmada bundan sonra sosyal pazarlama müdahalelerinde sıkça kullanılan teoriler ve modeller açıklanacaktır. Bunlar Değişim (Mübadele) Teorisi, Sağlık İnanç Modeli, Korunmaya Güdülenme Teorisi, Gerekçeli Eylem Teorisi, Sosyal Bilişsel Teori, Transteorik Davranış Değişikliği Modeli (veya Değişim Aşamaları Modeli), Yeniliklerin Yayılması Modeli ile belirli bağlamlarda sözü edilen veya kullanılan diğer modeller ve teorilerdir.

\subsection{Değişim (Mübadele) Teorisi (Exchange Theory)}

Değişim teorisinin kökleri psikolojiye ve ekonomiye dayanmaktadır. Bu teoriye göre insanlar ihtiyaçları tarafından güdülen varlıklardır ve bu ihtiyaçları karşılayacak olan menfaatleri elde etmeye ve arttırmaya doğal eğilimleri vardır (Housten ve Gassenheimer, 1987). Bu kurama göre, bireyler sadece maddî varlıkları mübadele etmezler, maddî olmayan varlıklar da bu mübadele sürecine konu olabilir. İnsanlar beklenti sahibi oldukları menfaatlere göre davranışlarını yönetir ve ellerine geçecek menfaate göre karşılık verir (omerdemir.net).

Sosyal pazarlamanın ne olduğunu tanımlarken, yaklaşımı pazarlama kökleriyle ilişkilendirmek amacıyla "Değişim (Mübadele) Teorisi" kavramını kullanan pek çok araştırmacı vardır (örneğin, Hastings ve Saren, 2003; Kotler ve Roberto, 1989; Lefebvre ve Flora, 1988; Novelli, 1990). Bu teori çerçevesinde sosyal pazarlamacıların tüketicilerin değişime hazır olmaları karşılığında onlara faydalı olan bir şeyler sunmaları gerektiği belirtilir (Hastings ve Saren, 2003). Bu anlamda mübadele, iki ya da daha çok aktör arasındaki somut ya da soyut varlıkların değiş tokuşuyla gerçekleşir. Kotler (2000) mübadelenin gerçekleşebilmesi için beş ön koşulun gerçekleşmesi gerektiğini belirtir:

- En az iki tarafin bulunması.

- Her bir tarafın karşı tarafın değer vereceği bir şeye sahip olması.

- Her bir tarafın iletişim ve aktarım kabiliyetlerinin olması.

- Her bir tarafın karşı tarafın teklifini kabul ya da red özgürlüğüne sahip olması.

- Her bir tarafın karşı taraf ile iş yapmanın uygun ve arzu edilebilir olduğuna inanması.

Mübadelenin her bir taraf için faydalı olduğu bu varsayımların temelidir. Bu teoriye göre, sosyal pazarlamacı algılanan faydaların "satın alma maliyetinden" daha yüksek olduğuna tüketicleri ikna edebilirse, tüketicinin gönüllü davranış geliştirme olasılığı artar (Maibach, 1993). İnsanların, fiilen yapmadan önce bir davranışı gerçekleştirmenin maliyetlerini ve faydalarını karşılaştırması doğal olandır. Bireylerin bir davranışı gerçekleştirmesi için faydaların maliyetten ağır basması gerekir. Değişim teorisi, bir hedef kitlenin istenen bir davranış değişikliğiyle ilişkilendirdiği maliyetlerin ve faydaların anlaşılması için sosyal pazarlamacılara bir perspektif sağlar. Bu teori istenilen davranış değişikliğini yapmak karşılığında hedef kitleye istedikleri faydaları sunarak uygulanır (www.orau.gov)

Sosyal pazarlama başlığ 1 altında değişim (mübadele) teorisine üç temel itiraz geliştirilmektedir (Hastings ve Saren, 2003). İlk olarak, mübadelenin doğasının sorunlu olduğu çünkü müşterilerin elde edebileceği faydaların genellikle ticari pazarlamadan daha belirsiz olduğu belirtilir. Ticari pazarlamada mallar ve hizmetler karş1lı̆̆ında para takas edilir, oysa sosyal pazarlamada genellikle psikolojik, sosyal ya da diğer soyut değerlerin mübadelesi yani sembolik değişimi söz konusudur. Sosyal pazarlama ilişkilerinde en çok ortak faydaya ulaşma hedeflenmektedir. Fakat iktisadi alış-verişte karşılık elde etme esastır. Bu soyut ve sembolik değişim ilişsisi sosyal pazarlamacının işini ticari pazarlamaya göre daha problematik kılar. Örneğin hiç tecrübe etmediği ya da algılamadığı AIDS'e, Hepatit B'ye yakalanma riskine yönelik bir davranış değişimi için insanları ikna etmek çok daha zordur. Ancak bununla beraber ticari pazarlamanın da marka ve imaj yönetimi gibi soyut

Selçuk Üniversitesi Sosyal Bilimler Meslek Yüksekokulu Dergisi, Yıl: 2020 Cilt: 23 Sayı:2 
alanlarda mücadelesi söz konusudur. Bu konudaki en bariz örnek modadır. Dolayısıyla "soyut varlıkların” satış yönetiminden pazarlama disiplinin iki kolu da istifade edebilir (Hastings ve Saren, 2003).

İkincisi, sağlık müdahalesi uygulamacıları mübadele mantığından kaçınmakta ve birer sağlıkçı olarak kendilerinin fayda elde etmesi fikrine karşı çıkmaktadırlar. Söz konusu uygulamacılar mübadele mantı̆̆ının sağlı müdahalelerinin "fedakarlık" temelinin altını oyacağını düşünmektedirler (Buchanan vd., 1994; aktaran Hastings ve Saren, 2003).

Üçüncüsü, ise değişim teorisinin cevaplamasının zor olduğu bir itirazdır. Söz konusu itiraz Kotler'in (2000) yukarıda sıralanan ön koşullarından üçüncü ve dördüncüsüne ayrıca güçler dengesi varsayımına temas etmektedir. Sosyal pazaramacılar hedef kitlenin iletişim ve aktarım kabiliyeti ile davranış değişimini kabul ya da red özgürlüğünü garanti edememektedir. Örneğin sağlıklı yaşam ve beslenmeye yönelik bir kampanyada düşük gelirli kesimleri fitness salonlarına kaydolmaya ya da organik meyve ve sebze tüketimine ikna edemezsiniz. Ayrıca bu tip dezavantajlı gruplar pazarlama sunumlarına yapıcı bir şekilde yanıt verecek eğitim seviyesinden ve kişisel becerilerden de çoğu zaman yoksundur. Covid-19 salgınında gözlemlenen düşük gelir seviyesi ile yakalanma riski arasındaki güçlü ilişki bu endişeyi desteklemektedir.

Bununla birlikte bahsedilen itirazlar değişim teorisinin hiç bir koşulda işlemeyeceği anlamına gelmez. Ticari pazarlama fikirlerini zorlu sosyal sorunlarda kullanmak, yaklaşımın kavramsal sağlamlığını test edecek ve pazarlama fonksiyonun rolü hakkında daha iyi bir anlayış sağlayacaktır (Hasting ve Saren, 2003). Özetle, değişim teorisinin hala doğrulanması ve sağlık müdahaleleri konusunda yapılan itirazların üstesinden gelinmesi gerekmektedir. Fakat değişim teorisinin sağlık çerçevesindeki insan davranışlarının anlaşılmasını derinleştirme potansiyeli gözden kaçırılmamalıdır.

\subsection{Sağlık İnanç Modeli (Health Belief Model)}

Sağlık inanç modeli (SIM), halk sağlığı uygulayıcıları arasında en yaygın kullanılan teorilerden biridir ve başlıca ilkeleri çok sayıda sosyal pazarlama projesine girmiştir. Bu model başlangıçta insanların neden hastalıkları önlemek veya tespit etmek için hazırlanan programlara katılmadıklarını açıklamak için tasarlanmıştır (Lefebvre, 2000). SİM, insanların sağlıkla ilgili koruyucu davranışlara uyma kararlarına açıklık getirmek (Apay, 2007), sağlığa ilişkin davranışların temel unsurlarını tespit etmek ve daha sonra bu davranışları değiştirmek için kullanılmaktadır (Özata ve Kapusuz, 2019). Sağlık taraması çalışmalarından hastalıkları önlemeye dönük çalışmalara kadar birçok alanda uygulanmıştır. Sağlık inanç modelinde insanların hastalıklar konusunda önleyici davranışı gerçekleştirip gerçekleştirmeyeceklerini etkileyen bazı ana bileşenler vardır (bkz. Şekil 1).

\section{Şekil 1: Sağlık İnanç Modeli}

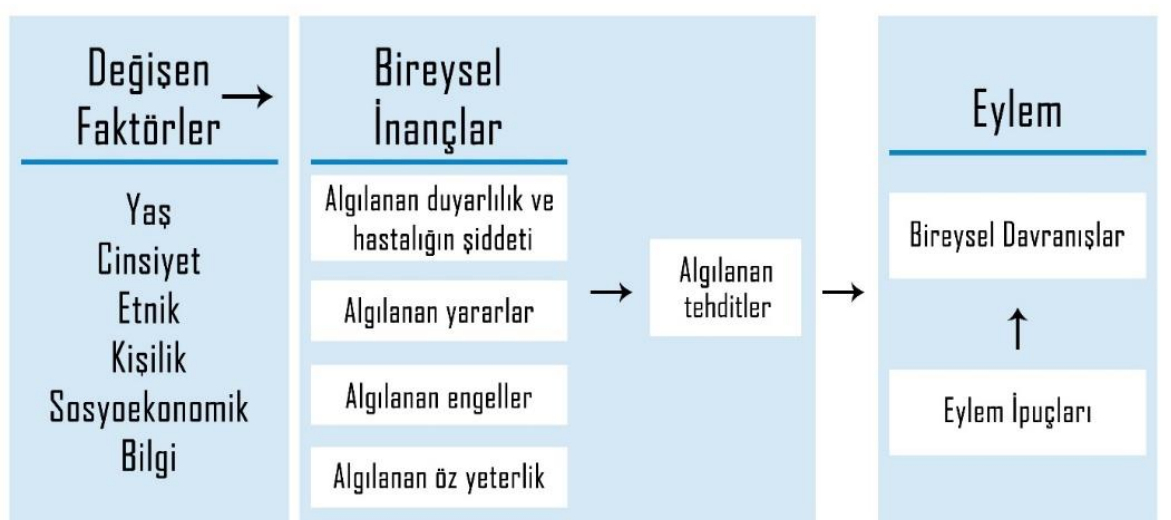

Kaynak: "Health Behavior and Health Education: Theory, Research, and Practice" (4th Edition), Glanz, K., Rimer, B.K. ve Viswanath, K., 2008, San Francisco, CA, US: Jossey-Bass, s. 49 aktaran Özata ve Kapusuz, 2019:71.

Yukarıdaki şekilde verilen SİM'in temel bileşenleri şunları içerir (Lefebvre, 2000; Özata ve Kapusuz, 2019):

- Algılanan duyarlılık: Belirli bir sağlık sorunun gelişimine yönelik risk algısı.

- Algılanan şiddet: Belirli bir sağlık sorununun sonuçlarının ciddiyeti hakkında düşünceler.

- Algılanan faydalar: Duyarlılığı ve şiddeti, yani tehditi azaltabilecek çeşitli eylemlerin etkinliği hakkındaki inançlar (ilk iki bileşen birlikte ele alındığında "tehdit" olarak adlandırılır).

- Algılanan engeller: Özel önlemler almanın potansiyel olumsuz yönleri.

- Eylemin ipuçları: Eylemi tetikleyen bedensel veya çevresel olaylar. 
- Öz yeterlilik: Sağlık davranışlarının (özellikle hayat tarzı değişikliklerinin zaman içinde sürdürülmesinin gerektirdiği daha karmaşık davranışların) bir öngörüsü

Çok çeşitli demografik, sosyal, psikolojik ve yapısal değişkenler bireyin algılarını ve dolaylı olarak sağlıkla ilgili davranışlarını etkileyebilir. Bunların en önemlilerinden bazıları eğitim durumu, önceki bilgiler, yaş, cinsiyet, etnik köken ve sosyoekonomik durumdur (Lefebvre, 2000; Özata ve Kapusuz, 2019). Dolayisıla sağlık müdahaleleri çerçevesinde tasarlanacak sosyal pazarlama kampanyalarının biçimlendirici aşamasında söz konusu sosyo-ekonomik ve demografik verilerin araştırılması büyük önem taşımaktadır. Bu teori sayesinde bireylerin uygulanan sağlık müdahelesinin faydasına olan inançlarını arttırmak ve onları ikna etmek kolaylaşacaktır.

\subsection{Korunmaya Güdülenme Teorisi (Protection Motivation Theory)}

Sağlık inançları modeli gibi korunmaya güdülenme teorisi (KGT) de sağlık davranışlarını açıklamaya çalışmaktadır. Rogers tarafindan ileri sürülen bu teori (Rogers, 1975, 1983; Rippetoe ve Rogers, 1987) bilgi kaynaklarının, özellikle de önceki davranışsal deneyimin bilişsel değerlendirmeleri teşvik ettiğini ve bunun da koruma motivasyonunu ortaya çıkardığını belirtmektedir (bkz. Şekil 3). Fakat bu kuram sağlık davranışlarını açıklarken korkuya odaklanmaktadır.

\section{Şekil 2: Korunmaya Güdülenme Teorisi}

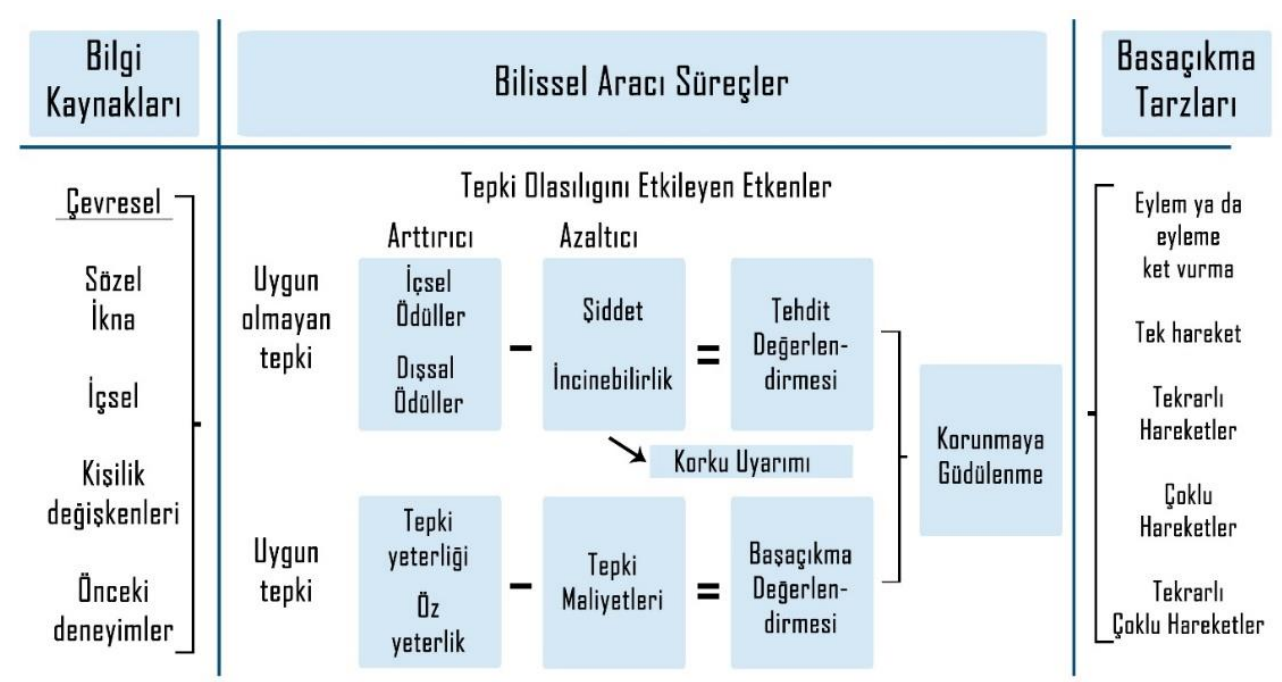

Kaynak: Adler vd.'den (1994) aktaran Apay, 2007:86.

Rippetoe ve Rogers'a (1987) göre önceki davranışlar bilişsel değerlendirmeleri harekete geçiren ve bir kişinin belirli bir olay ya da olguya karşı nasıl tepki vereceğini belirleyen çeşitli tehdit edici bilgi kaynaklarından biridir. Araştırmacılar iki bilişsel boyut belirtilmiştir. Bunlar tehdit ve başa çıkma değerlendirmeleridir.

İnsanlar tehdidin büyüklüğüne ve bu tehditle yüzleşme ihtimallerine bağlı olarak uygun olmayan davranışlarda bulunmaktan kaçınabilir (Apay, 2007). Örneğin Covid-19 salgını döneminde kalabalık ortamlardan kaçınmak, sosyal mesafeyi korumak ve maske takmak gibi. Başa çıkma değerlendirmelerinde bireyin tavsiye olunan davranışın tehdidi hafifleteceğine olan inancı (tepki yeterliği), ayrıca tavsiye edilen davranışı sergileyebileceğine yönelik inancı (öz yeterlik) uygun davranışı ortaya koyma ihtimalini yükseltir (Apay, 2007). Örneğin bireyin sosyal ortamlarda yaptı̆̆ı sportif ve sanatsal faaliyetlere salgın sürecinde ara vermesinin bulaşma riskini azaltacağını düşünmesi gibi.

Umeh (2004) tehdit ve başa çıkma değerlendirmelerinden başka uyumsuz başa çıkma değerlendirmelerinden bahsetmektedir. Yazar, uyumsuz başa çıkma davranışlarının, tehlikeyi ortadan kaldırmak yerine kaygıyı azaltmaya odaklanığı beliritir. Örneğin insanlar tehditi reddedebilir (Covid-19 virüsü yalandan ibarettir) veya tamamen görmezden gelebilir (Ben genç ve sağlıklıyım, Covid-19 bana zarar veremez). Neuwirth ve diğerleri (2000; aktaran Apay, 2007:87) Korunmaya Güdülenme Teorisini aşırı kilolu bir hasta örneğini kullanarak şu şekilde açıklamaktadır:

"Bu örneğe göre, aşırı kilolu bir hastaya doktoru tarafindan mutlaka kilo vermesi gerektiğinin söylendiğini varsayalım. Bu hasta ilk olarak, kalp krizi geçirme ya da kalp çarpıntısı yaşama olasılığının yüksek olduğuna (tehdit olasılı̆̆l) inanmalıdır. Bu hastalıkların da aile ortamlarında (dışsal ödüller) doymuş yă̆ oranı yüksek besinler tüketmekten (içsel ödül) daha önemli olacak kadar istenmeyen bir durum (zararın şiddeti) olduğuna 
karar vermelidir. Beslenmesini değiştirme kararı verebilmesi için, hastanın az yağlı besinler tüketmenin gerçekten kalp krizi geçirme ya da kalp çarpıntısı yaşama olasılığını azaltacağına (tepki yeterliği) ikna olması gerekmektedir. Hastanın aynı zamanda, diyet programı ve diyet yiyeceklerini hazırlamak için daha fazla çaba ve zaman harcamak (tepki maliyetleri) zorunda kalmasına rağmen, böyle bir diyete uyabilmesi de (öz yeterlik) gerekmektedir."

Sağlık inançları modelinde olduğu gibi korunmaya güdülenme teorisi de insanların sağlık davranışlarının anlaşılmasını sağlamaktadır. KGT'de açıklanan bilgi kaynakları, bilişsel aracı süreçler ve başaçıkma tarzları sağl1k müdahaleleri planlayan sosyal pazarlamacıların betimleyici araştırma, uygulama ve değerlendirme faaliyetlerine önemli ölçüde destek verecektir. Betimleyici araştırmada doğru bir şekilde tanımlanan mevcut sağlık davranışları ve bunlara temel teşkil eden bireysel faktörler, değişimin ortaya çıkarılmasının hedeflendiği uygulama aşamasında doğru stratejilerin oluşturulmasını sağlayacaktır. Yine davranış değişiminin ne ölçüde ve hangi nedenlerle ortaya çıktığı KGT ile ölçülerek program sonundaki değerlendirmelerin daha doğru bir biçimde yapılması mümkün olacaktır.

\subsection{Gerekçeli Eylem Teorisi (Theory of Reasoned Action) ve Planlı Davranış Teorisi (Theory of Planned Behavior)}

Davranışı tanımlamada sosyal psikoloji pespektifini kullanan ve literatürde çokça kullanılan teorilerden birisi Fishbein ve Ajzen (1975) tarafından geliştirilmiş olan gerekçeli eylem teorisi (Şekil 3) ve diğeri de onun Ajzen (1985) tarafından geliştirilmiş versiyonu olan planlı davranış teorisidir (Şekil 4). Gerekçeli Eylem Teorisine (GET) göre bir davranış, o davranışa ilişkin niyetin bir sonucudur. Bu davranışsal niyet, kişinin davranışa yönelik tutumlarının ve davranışla ilgili subjektif normlarından etkilenir (Lefebvre, 2000). Niyet kavramının iki temel belirleyicisi vardır. Bunlardan birincisi bireylerin belirli bir davranışı sergilemeye yönelik tutumları (davranışa yönelik tutumlar), ikincisi ise kişilerin belirli bir davranış1 gösterme/göstermeme konusunda algıladığ sosyal baskı ya da destektir (subjektif norm). GET’e göre, kişiler belirli bir davranış hakkında pozitif bir değerlendirme sahibiyse ve sosyal çevresinde önemsediği kişilerin de kendisinin bu davranışı sergilemesini desteklediğini algılıyorsa, ilgili davranışı göstermek niyetine sahip olacaktır (Kocagöz ve Dursun, 2010).

\section{Şekil 3: Gerekçeli Eylem Teorisi Modeli}

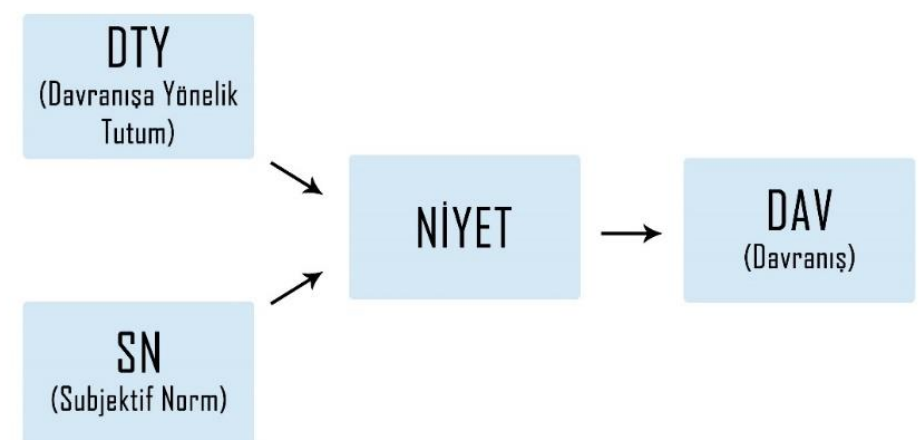

Kaynak: Kocagöz ve Dursun. 2010. KMÜ Sosyal ve Ekonomik Araştırmalar Dergisi 12 (19) 139-152.

GET, sağlık ve sosyal pazarlama gibi farklı alanlarda uygulanmış (Luca ve Suggs, 2013) ve modeldeki bileşenlerin davranışı ve davranışa dair niyetleri tahmin etme yeteneği bakımından performansının yüksek olduğu görülmüştür (Manstead, 2001; aktaran Kocagöz ve Dursun, 2010). Ancak GET kişinin davranış üzerinde tam iradesinin olduğu durumları açıklamaktadır. Oysaki bireylerin davranışları bazen kendi iradesi dışında gerçekleşebilir. Bu nedenle GET'in bir uzantısı olan Planlı Davranış Teorisi (PDT) ise, kişinin davranışının performansı üzerinde algılanan davranışsal kontrolü (ADK) yani kişinin kendi kendine yeterlilik durumunu dâhil eder (Lefebvre, 2000). Burada bireylerin davranışa dâhil olacak kaynakların ve engellerin varlığı ya da yokluğuyla bağlantılı olarak davranış üzerinde algılanan kontrollerinin gücü belli olacaktır. Yine çevrede algılanan her bir kaynağın ve engelin gücüne bağlı olarak davranış üzerinde algılanan kontrolün büyüklüğü belli olacaktır. 


\section{Şekil 4: Planlı Davranış Teorisi Modeli}

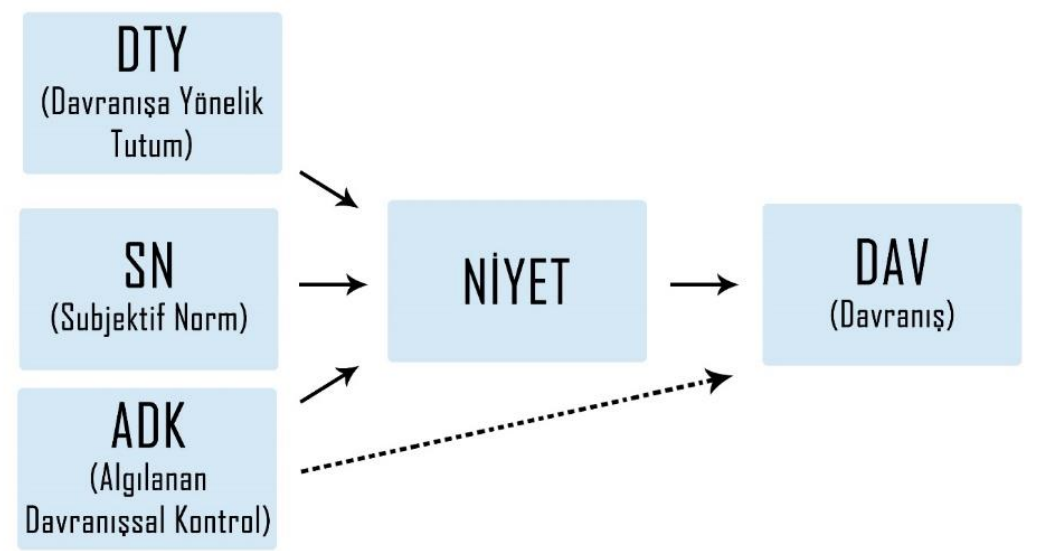

Kaynak: Kocagöz ve Dursun. 2010. KMÜ Sosyal ve Ekonomik Araştırmalar Dergisi 12 (19) 139-152.

PDT Modeli GET Modelini kapsamakta ve ilgili modelde davranışa yönelik tutum, sübjektif norm ve algılanan davranışsal kontrol bileşenleri niyet üzerinden davranışı açıklamaktadır. Şekil 4'de algılanan davranışsal kontrol ile davranış arasındaki bağlantının kesik çizgilerle belirtilmesinin nedeni, algılanan davranışsal kontrolün bazen aracısız yani doğrudan davranışı açıklayabilme olasılı̆̆ıdır (Kocagöz ve Dursun, 2010).

Montano, Kasprzk ve Taplin (1997) GET ve PDT’ye ilişkin yaptıkları incelemelerde şunu belirtir: “Belirli bir davranış veya toplulukla ilgili davranışsal sonuçları, etkileşim içinde olduğumuz bireyleri, kolaylaştırıcı ve kısıtlayıcı faktörleri belirlemek için derinlemesine ve açık uçlu mülakatlar yapılmasının önemi yeterince vurgulanmamaktadır" (s. 109). Bu mülakatlar projenin erken planlama aşamalarında yapılır ve genellikle davranışı uygulamayı düşünen ve düşünmeyenler arasında eşit dağılım gösteren 15-20 katılımcı içerir. GET ve PDT, bu mülakatlar için ortak bir çerçeve oluşturur ve bu çerçeve yoluyla mülakat çabalarının odağında hangi inançların olması gerektiği belirlenebilir (Lefebvre, 2000).

Sosyal pazarlamacılar eksik olmasına rağmen çoğu zaman GET ve PDT kullanırlar. Subjektif normlar ve referanslar teorik modele aşina olunmasa da, örneğin genç yaşta tütün kullanımını önlemede olduğu gibi, genellikle sosyal pazarlama programlarının odak noktasıdır. GET “denkleminin” bu yarısına büyük dikkat gösterilmesine rağmen, davranışın kendisine yönelik tutumların nasıl değiştirileceğine ilişkin bir endişeye pek rastlanmaz (Lefebvre, 2000) . Bu duruma istisna olarak, "Sağlık İçin Günde 5 Defa" programı (Sutton vd., 1995) verilebilir. Bu programdaki biçimlendirici araştırma, hedef kitlenin günde 5 porsiyon meyve ve sebze yiyen insanları kendilerinden daha az yetenekli, daha az güvenilir, daha az kibar ve daha az dost canlısı olarak algıladığını ortaya koymuştur. Bu içgörü, program planlamacılarına programın imajını oluştururken bu olumsuz tutumlara karşı koyabilecek materyaller tasarlama ve geliştirmede yardımcı olmuştur.

\subsection{Sosyal Bilişsel Teori (Social Cognitive Theory)}

Sosyal Bilişsel Teori (SBT) davranışı, bazı etkenlerin birbirlerinin etkileşimli belirleyicileri olarak işlev gördüğü triadik karşılıklılık (karşılıklı determinizm) olarak açıklar (Lefebvre, 2000). Bu etkenler bilişsel faktörler, kişilerarası faktörler ve çevresel olaylardır. Özata ve Kapusuz SBT'nin temel kavramlarının beş kategoride gruplandığını belirtmektedir (2019:72):

- Davranışın psikolojik belirleyicileri,

- Model alarak öğrenme,

- Davranışın çevresel belirleyicileri,

- Öz kontrol,

- Ahlaki geri çekilme

Önceki teorik modellerin aksine SBT, davranışın sadece içsel faktörlerle belirlenmediğini ve bir bireyin sadece çevresinin bir ürünü olmadığını söyler. Bireyler aynı zamanda ortaya koydukları eylemler, kişisel özellikleri, çevrelerine ve aslında çevrelerinde ne olduğuna verdikleri tepkilerle davranışlarını serglemektedirler. Bu üç faktörden herhangi birindeki değişikliğin diğerlerinde de değişikliğe yol açtığ1 varsay1lmaktadır (Lefebvre, 2000).

SBT'deki anahtar kavramlardan biri de çevresel değişkenler arasında yer alan gözlemsel öğrenmedir. Daha önceki davranış teorilerinin aksine SBT, çevreyi sadece davranışları güçlendiren veya cezalandıran bir ortam olarak görmez. Bu teori aynı zamanda çevreyi, insanların başkalarının eylemlerini izleyebilecekleri ve bu 
davranışlarının sonuçlarını öğrenebilecekleri bir ortam olarak görür. Gözlemsel öğrenmeyi düzenleyen süreçler şunları içerir (Lefebvre, 2000):

- Dikkat: Dikkat çekmek ve sürdürmek

- Bellek: Hatırlanmak

- Üretim: Gözlemlenen davranışın yeniden üretilmesi

- Motivasyon: Davranışı üretmeye teşvik edilmek

SBT'nin diğer temel bileşenleri şunlardır (Lefebvre, 2000):

- Öz-yeterlik: Kişinin belirli bir performans seviyesine ulaşma kabiliyeti.

- Sonuç beklentisi: Davranışların üreteceği muhtemel sonuç hakkında beklenti ya da davranışın sonuçlarına verilen değer.

- Duygusal başa çıkma tepkileri: Psikolojik savunma (inkar, baskı), problemi yeniden yapılandırma ve stres yönetimi gibi bilişsel teknikler dâhil, duygusal uyaranlarla başa çıkmak için kullanılan stratejiler.

- Etkin öğrenme: Kişinin eylemlerinin sonuçlarından bir şeyler öğrenmesi.

- Kural öğrenimi: Çoğunlukla dolaylı süreçler ve yeteneklerle (doğrudan deneyime kıyasla) elde edilen davranış kalıplarını oluşturmak ve düzenlemek.

- Kendine çekidüzen verme yeteneği: Davranışların çoğu iç standartlar ve bireyin kendi eylemlerine yönelik kendini değerlendirme tepkileri tarafından motive edilir ve düzenlenir.

SBT, insan davranışını açıklamaya yönelik daha kapsamlı çabalardan biri olarak görülmektedir (Baranowski vd., 1997). Karşılıklı determinizm ve öz-yeterliliğe odaklanması (ikincisi, yukarıda görüldüğü gibi, diğer teorik modeller tarafından da benimsenmiştir), sosyal pazarlamacılara güçlü bir teorik alt yapı sağlar. Bu alt yapı ilköğretim çağıdaki çocuklar için uygulanan "Team Nutrition” programı gibi bireysel odaklı programları tamamlayan çevresel müdahalelerin doğmasına yol açmıştır (Lefebvre vd., 1999). Bu araştırma projesinin önemli bir bulgusu, çocukların "Team Nutrition" mesajlarına maruz kaldıkları iletişim kanallarının davranış değişikliği üzerinde en çok etkiye sahip olmasıdır.

SBT aynı zamanda program planlayıcılarına hedef kitlenin istenen davranışı gerçekleştirme kabiliyetlerini, bu eylemin beklenen sonuçlarını ve bu sonuca verdikleri değeri analiz etmelerini öğütler. Bundan başka SBT, seçilen hedef kitle için yeni davranışları modelleme girişimlerinin altını çizer, yeni davranışların etkili bir şekilde öğrenilmesi ve gerçekleştirilmesi için dikkat, bellek, üretim ve motivasyon süreçlerinin ele alınması gerektiğini ögütler (Lefebvre, 2000).

Sosyal öğrenme teorisinin geliştirilmiş bir versiyonu olan sosyal bilişsel teorinin sosyal pazarlamada kullanımına çokça rastlanmaktadır (örn. Huhman vd., 2007; Lefebvre vd., 1999; Price vd., 2008; Wong vd., 2004). Luca ve Suggs (2013) sosyal pazarlama mühadale stratejileri oluşturmada ve değerlendirme çalışmalarında planlı davranış teorisi ile birlikte sosyal bilişsel teorinin de pozitif rolü olduğunu belirtmektedir. Yazarlar gençlerde fiziksel aktivitenin arttırılmasına yönelik "VERB" adlı kampanyada (bkz. Berkowitz vd., 2008) sosyal bilişsel teorinin kullanılmasının olumlu sonuçlar verdiğini aktarmaktadır.

\subsection{Sağlık Davranışı Değişikliğinin Transteorik Modeli (The Transtheoretical Model of Health Behavior Change)}

Genellikle "Değiş̧im Aşamaları" olarak bilinen bu model, psikoterapi ve davranış değişikliği teorilerinin karşılaştırılması ve analizi çerçevesinde geliştirilmiştir. Sigara tüketimi ile başlayıp alkol, madde bağımlılığı, obezite, mamografi ve kanser taraması gibi sağlık müdahalelerine ilişkin uygulama ve araştırmaları kapsayacak biçimde model zamanla geliştirilmiştir (Özata ve Kapusuz, 2019).

Transteorik model sosyal pazarlama programlarında sıkça kullanılan modellerden biri haline gelmiştir. Bu model, 1990'ların başında toplumdaki bireylerin fiziksel aktivite düzeylerini artırmak için sosyal pazarlama programları tarafından uygulanmasına rağmen (Marcus vd., 1992; aktaran Lefevbre, 2000), Andreasen tarafından "Pazarlamada Sosyal Değişim" (1995) adlı eserde teorik model olarak birleştirilmiş hali şüphesiz birçok sosyal pazarlamacı tarafindan benimsenmesine ön ayak olmuştur.

Model, on farklı değişim sürecinin tanımlandığı önde gelen psikoterapi ve davranış değişikliği teorilerinin bir analizinden ortaya çıkmıştır. Bu süreçler daha sonra insanları altı belirli değişim aşamasından geçirmek için en uygun olan belirli müdahale türlerini önerir. Prochaska ve Vilicer (1997) tarafindan tanımlanan süreçlerden bazıları şunları içerir:

- Bilinç arttırma: Sorunlu bir davranışın nedenleri, sonuçları ve tedavileri konusundaki farkındalığı artırır. Geri bildirim, eğitim, yüzleşme ve medya kampanyaları olası müdahale yöntemleridir. 
- Kendini yeniden değerlendirme: Belirli bir sağlıksız davranışı olan ve olmayan kişinin kendi oluşturduğu görüntüye ilişkin değerlendirmelerini kullanır. Değerlerin açıklı̆̆a kavuşturulması, sağlıklı rol modelleri ve görüntü teknikleri insanların değerlendirmelerine yardımcı olabilir.

- Sosyal özgürlük: Özellikle hâlihazırda görece yoksun bırakılmış veya ezilmiş kişiler için sosyal firsatları veya alternatifleri artırır. Savunuculuk, yetkilendirme teknikleri ve politika değişiklikleri bu hedeflere ulaşmak için kullanılabilecek prosedürlerdir.

- İlişkilere yardım etmek: Sağlıkta davranış değişikliği için bakım, güven, açıklık, kabul ve desteği birleştirir. İlişki kurma, danışman çağrıları ve arkadaşlık eşleştirme sistemleri gibi stratejiler bu tür bir destek için kaynaklar olabilir.

Modelin en popüler olup en çok kullanılan tarafı aşamaların kendisidir ve şunları içerir (Prochaska ve Velicer, 1997, s.39):

- Ön düşünme: Bu aşamada insanlar öngörülebilir bir gelecekte harekete geçme niyetinde değillerdir, süresi genellikle önümüzdeki altı ay olarak belirtilir.

- Derin düşünme: Bu aşamadaki insanlar, önümüzdeki altı ay içinde harekete geçmeyi (davranış1 değiştirmeyi) planladıklarını belirtirler.

- Hazırlık: Bu aşamada insanlar önümüzdeki ay harekete geçeceklerini ve bir eylem planına sahip olacaklarını belirtirler.

- Eylem: Bu aşamada, insanlar son altı ay içinde belirli davranış değişiklikleri yapmış olurlar.

- Sürdürme: $\mathrm{Bu}$ aşamadaki insanlar, davranışın tekrarını önlemek için çalışırlar ve değişiklikleri sürdürmelerine yardımcı olmak için daha önce açıklanan işlemlerin çoğunu kullanırlar. Bu aşama 6 ay ile 3 yıl arası sürer.

Son verme: Bireylerin eski davranışın cazibesine kapılmadığ $1 \% 100$ öz-yeterliliğe sahip olduğu aşama olarak tanımlanır. Bu aşamadaki insanlar eski davranışlarına veya alışkanlıklarına geri dönmeyeceklerinden emindir.

Modeldeki diğer kavramlar arasında karar dengesi (değişimin artılarını ve eksilerini tartmak), öz yeterlik ve cezbedici faktörler (olumsuz etkiler veya duygusal sıkıntının rolü, olumlu sosyal durumlar ve tutku) yer alır. Modelin sosyal pazarlamacıları götürdügü nokta, hedef kitlenin nispeten az üyesinin eylem odaklı programlara hazır olması ve insanları içinde bulundukları önceki aşamalardan uzaklaştırmak için daha fazla zaman ve enerjinin diğer süreçlere (örneğin, bilinç arttırma, sosyal özgürlük) odaklanarak sarfedilmesi gerektiğidir. Prochaska ve Velicer'in (1997) araştırması, insanların belirli aşamalarda belirli süreçleri kullandıklarını ve genel olarak deneyimsel süreçlerin (bilinç arttırma, çevrenin yeniden değerlendirilmesi, kendini yeniden değerlendirme ve dramatik rahatlama) ön düşünme ve düşünme aşamalarındaki insanlar için en uygunu olduğunu göstermektedir. Eylem ve sürdürme aşamalarındaki kişilerin acil durum yönetimi, yardım ilişkileri, karşı koşullandırma ve uyaran kontrolü gibi davranışsal süreçleri kullanma olasıllğı daha yüksektir. Müdahaleleri bir kişinin içinde bulunduğu aşamayla eşleştirmek, davranış değişikliğine yol açan programın etkililiğinde kritik bir faktördür.

Prochaska ve Velicer (1997) ayrıca, insanların çeşitli sağlık davranışları için aşama kaydettikçe "artıların ve eksilerin" nasıl değiştiğini inceleyen 12 çalışma hakkında bilgi vermektedir. Her durumda, "eksiler", ön düşünme aşamasındaki insanlar için değişimin "artılarını" açıkça geride bırakmaktadır. Kişi derin düşünme aşamasındayken, "artıların" sayısı artmakta ve aynı kalan "eksilerin" sayısını aşmaktadır. Derin düşünmeden eyleme geçmek, "artılar" sabit kalırken veya biraz daha artarken "eksilerin" sayısının azalmaya başlamasını gerektirir. "Artılar ve eksiler" arasındaki matematiksel ilişkileri inceleyen araştırmacılar, bir kişinin ön düşünmeden eyleme geçmesi için artıların, eksilerin azalmasının iki katı kadar artması gerektiği sonucuna varmıştır. Buradan sosyal pazarlamacılar için yapılacak çıkarım, değişimin faydalarını artırmak için, algılanan maliyetleri ve engelleri azaltmaya göre belki de iki kat daha fazla çaba harcanması gerektiğidir.

\subsection{Yeniliklerin Yayılması Modeli (Diffusion of Innovations)}

Büyük insan gruplarının davranışlarını etkilemeye çalışan sosyal pazarlamacıların önem verdiği modellerden biri de yeniliklerin yayılması modelidir. Her hangi bir sosyal müdahale sahasında "yeniliklerin yayılması için gereken adımları ve süreçleri anlamada kullanılmaktadır” (Özata ve Kapusuz, 2019:73). Kotler ve Roberto (1989) yenilik yayılmasını araştırmış ve sosyal pazarlama programlarına uygulanmasını incelemiştir. $\mathrm{Bu}$ incelemede, birçok araştırmaya dayanarak tespit ettikleri ilk noktalardan biri, yeni bir davranışı benimsemek için farklı motivasyonları olan farklı türden insan gruplarının varlığı olmuştur. Rogers (1983) kadar detaya girmeseler de Kotler ve Roberto (1989) da bu grupları beş başlikta irdelemiştir:

- Yenilikçiler (\% 2,5): Bu grup yenilik ihtiyacı ve farklılık gereksinimi hisseder.

- Erken Benimseyenler (\% 13,5): Yenilikçilerle temasın sonucu olarak benimsemenin değerini anlarlar. 
- Erkenci Çoğunluk (\% 34): Daha çok bilinçli bir şekilde başkalarını taklit etme veya onlarla eşitlenme ihtiyac hissederler.

- Geç kalan Çoğunluk (\% 34): Erken çoğunluğun değişikliği onayladığını gördüklerinde çoğunluğa uyum sağlama ihtiyacı hissederler.

- Geç kalanlar (\% 16): geleneklere saygı duyma ihtiyacı hissederler.

Rogers (1983) bu beş grubun demografi, iletişim modelleri ve diğer değişkenler açısından nasıl farklılaştığı konusunda ayrıntılara girmiştir. Yenilik kavramlarının ikinci bir yayılma grubu, yayılmanın hızının ve kapsamının belirleyicileri etrafında odaklanır. Bu özelliklerden bazıları şunlardır (Oldenburg vd., 1997):

- Göreli avantaj: Yeni davranış şu anda yaptıklarından daha iyi, daha kolay ve daha basit mi?

- Uyumluluk: Yeni davranış hedef kitlenin yaşam tarzına, kültürel/etnik inançlarına ve uygulamalarına, öz imajına uyuyor mu?

- Denenebilirlik: Davranış nihai bir taahhüt vermeden önce denenebilir mi?

- İletilebilirlik: Davranış net ve kolay anlaşılabilir mi?

- Risk: Davranış minimum risk ve belirsizlikle benimsenebilir mi?

Yenilik araştırmaları ve kavramlarının yayılması, sosyal pazarlamacıların programlarını tasarlarken kullanmaları için önemli miktarda içgörü sağlar. Ancak sosyal pazarlama çevrelerinde bu konuda çok az aktif tartışma görülmektedir. Yeniliklerin yayılması birçok "büyük" fikre sahiptir, fakat kısıtlı bütçeler ve kısa zaman vadeler söz konusu olduğunda bu fikirler önemsenmemektedir. Örneğin, benimseyenler sınıflandırması kavramının temeli, bir veya iki sınıflandırma ile (yenilikçiler ve erken benimseyenler) başladığınız ve yalnızca benimseme başarılı olduğunda "daha büyük sayılara" geçtiğiniz anlamına gelir. Zaman içinde aşamalı yaklaşımların, öncelikler değiştiğinde ve bütçeler uyarılmaksızın kısıtlandığında ve genişlediğinde planlanması ve uygulanması genellikle imkansızdır. Yine de diğer konseptler benimsemenin nasıl daha hızlı ve verimli bir şekilde yapılacağına ilişkin kaynaklar üzerine minimum etkiyle model çerçevesinde uygulanabilir. Bu bölümün başında bahsedildiği gibi, yayılma modeli sosyal pazarlamacıların kullanabileceği birkaç nüfus odaklı modelden biridir. Nihayetinde davranış değişikliğinin bireysel düzeyde gerçekleştiği noktaya varılabilirken, yayılma araştırması, geniş kapsamlı davranış değişikliğini yönetmek ve bunu şansa bırakmamak için kullanabilinecek süreçler olduğunu öne sürmektedir (Lefevbre, 2000).

\subsection{Paydaş Teorisi (Stakeholder Theory)}

Sosyal pazarlamada değişimi hedefleyen aktörlerin üzerinde durması gereken bir başka önemli faktör paydaşlardır. Paydaşlar bir firmanın ya da kurumun faaliyetlerini etkileyen ya da ilgili faaliyetlerden etkilenen tarafları ifade eder (Freeman, 1984). Yaygın olarak kullanılan bir yönetim teorisi olan paydaş teorisi, paydaş gruplarının "ihtiyaç ve endişelerini" anlayarak rekabetçi bir piyasa ekonomisinde kurumsal şirketlerin hayatta kalma olasılıklarını iyileştirmeyi ve bu grupların desteğini sağlayarak performans sürekliliği ve gelişimi sağlamayı amaçlamaktadır (Buyucek vd., 2016). Paydaşlar, davranışsal değişimi yaratan fikirlerin üretilmesi (ürün), finansmanı (fiyat), yayılması (yer) ve farkındalığının (tanıtımı) artırılması çerçevesinde önemli bir rol oynarlar. Paydaşların sosyal pazarlama faaliyetlerinin hedefine ulaşmasında üstlenebileceği önemli rollerin ve ortaya koyacakları katkıların altını çizen Buyucek vd. (2016), Paydaş Teorsinin sosyal pazarlamada kullanılmasını önermektedir.

Bir şirketin hayatta kalmasını etkileyen ve bundan etkilenen birçok taraf yani paydaş vardır. Paydaşların planlanan faaliyetlere katılım göstermek konusundaki endişeleri düşük performansa ve hatta başarısızlığa neden olabilir. Bu nedenle başarılı şirketler karar verme aşamasında paydaşları dikkate alma eğilimindedir (Kotler vd., 2010). Paydaşların katılımı iş dünyasında olduğu gibi sosyal pazarlama sahasında da çok önemli bir faktördür. Uygulamada sosyal pazarlamacılar, sınırlı zaman, finansman, insan kaynakları ve doğal kaynaklar gibi yönetim literatüründe tanımlanan kısıtlamaların birçoğuyla karşı karşıya kalırlar. Bu kısıtlar sosyal pazarlamacıların uygulama yeteneklerini sınırlandırır. Dolayısıyla bu kısıtların ortadan kaldırılmasına destek verecek paydaşlara ihtiyaç doğar. Her sosyal pazarlama müdahalesinin farklı bir bağlamı, kaynakları, hedef grupları ve amaçları söz konusudur. Bu nedenle paydaşların mevcudiyetine, erişimlerine ve imkânlarına bağlı olarak sosyal müdahalelere katılımı göz önünde bulundurulmalı ve tanımlanmalıdır.

Sosyal pazarlama müdahaleleri her zaman birden fazla paydaşla etkileşimleri içerir. Sosyal pazarlama müdahalelerinde farklı paydaşlarla çalışmanın faydaları şu şekilde sıralanabilir (Buyucek et al., 2016; Kotler et al., 2010):

- Farklı paydaşların dâhil edilmesi davranış değişikliğine olan bağlılığın artmasını sağlayabilir,

- Tüketicilerin artık tecrit halinde olmadığı ve dijital ortamlar aracılığıyla birbirleriyle etkileşim halinde olduğu bir çağda eylemlere gönüllülerin katılımı arttırılabilir.

- Paydaşların sahip olduğu network gücü tanıtım ve farkındalık faaliyetlerini destekleyebilir. 
- Finans ve insan kaynağı ihtiyaçları karşılanabilir.

- Yerel ve ulusal düzeyde kamu otoritesinin desteği sağlanabilir.

Bu faydalarla birlikte Hastings (2003), hangi paydaşlara öncelik verileceğini ve bu paydaşların nasıl değerlendirileceğinin belirlenmesinin zorluğuna dikkat çekmektedir. Yazar davranış değişikliğinin bir gecede gerçekleşmediğini, dolayısıyla uzun vadeli planlama gerektirdiğini belirtmektedir. $\mathrm{Bu}$ çerçevede paydaş teorisi, sosyal pazarlama müdahalelerinde rol sahibi olan birden fazla paydaş arasındaki karmaşı ilişkilerin tanımlanmasına ve yönetimine gerekli desteği sağlamaktadır.

Davranışların farklı paydaşlar tarafından şekillendirilebilecek çok çeşitli çevresel faktörlerden etkilendiği göz önüne alındığında, farklı paydaşlar arasında sinerji sağlamak için verimli bir koordinasyona ihtiyaç vardır. Bununla birlikte, paydaşların sosyal pazarlama müdahalelerine katılımı çeşitli zorluklar doğurmaktadır. Sosyal pazarlamacıların sınırlı zaman ve müdahaleler için finansal kaynakların önemli bir baskısı altında olduğu göz önüne alındığında dikkatli paydaş yönetimi uygulamalarına ihtiyaç duyulduğu görülmektedir (Buyucek et al., 2016). Hangi paydaşların sürece dahil olması gerektiğini ve bu paydaşların sosyal pazarlama sürecinin hangi aşamasında destek vermesi gerektiğini (ör. biçimlendirici araştırma, uygulama ve değerlendirme) anlamak, bazı müdahalelerin neden davranışı değiştirdiğine (ve diğerlerinin neden değiştirmediğine) dair fikir verebilir. Biçimlendirici araştırma, uygulama ve değerlendirme aşamaları, önde gelen sosyal pazarlama akademisyenleri tarafından sosyal pazarlama sürecinde kilit aşamalar olarak tanımlanır. Bu nedenle sosyal pazarlamacılar bu aşamalara dahil edecekleri paydaşları önceden belirleyip her bir aşamaya dair faaliyetlerde etkin olarak sürece dahil ederlerse istedikleri davranış değişiminin ortaya çıkması kolaylaşacaktır.

Son olarak belirtilmelidir ki sosyal pazarlama sadece paydaşları belirli bir sosyal amaç için bir araya getirme fonksiyonu için hareket etmemelidir. Sosyal pazarlama bunun da ötesine geçerek her bir paydaşın kendi sektöründe ve farklı sektörlerdeki sosyal değer yaratan uygulamaları takip etmesini ve takdir etmesine çabalamalıdır. Örneğin ...işletmenin, STK'nın ya da devlet kurumunun aynı alanda çalışan bir rakibini ya da partnerinin iyi uygulama örneklerini takdir etmeyi becerebilmesi çok önemlidir. Bu zihinsel dönüşüm karş1 tarafi değil, esasen takdir edenin kendisini yücelten bir davranıştır. Zira rakibini ya da partnerini tebrik ve takdir eden kurumlar sosyal değer yaratan müesseselere değer verdiklerini ortaya koyarak kendi marka değerlerini ve imajlarını yükseltecektirler. Bu olumlu mesajlar aynı zamanda sosyal meselelere dair işbirliği atmosferi yaratacak ve paydaşlık ihtimali güçlenecektir. Covid-19 salgını sürecinde insan hayatının ne kadar hassas ve değerli olduğu daha iyi anlaşılmıştır. Bu nedenle sosyal pazarlama (Kotler ve Zaltman, 1971) ve pazarlama 3.0 (Kotler vd., 2010) gibi yaklaşımlarla artık genel anlamda bir zihniyet dönüşümünün hayata geçirilmesinin tam zamanıdır.

\section{DİĞER TEORILLER VE MODELLER}

Sosyal pazarlamacıların sosyal değişim programlarını planlarken ve uygularken hangi teori ve modelleri kullandığına dair hâlihazırda çok az kılavuz vardır. Zira pek çok araştırmacı ve uygulamacı çalışmalarının bu yönü hakkında bugüne kadar yeterli bilgi vermemiştir (Hastings ve Saren, 2003; Lefebvre, 2000; Luca ve Suggs, 2013). Ancak yapılan sistematik incelemelerde (örn. Buyucek vd., 2016; Lefebvre, 2000; Luca ve Suggs, 2013; Manikam ve Russell-Bennett, 2016) sosyal pazarlamacilar tarafindan sosyal müdahalelerde kullanılan belli başlı teori ve modeller öne çıkmıştır. Öne çıkan teori ve modeller Tablo 2'te gösterilmiş ve özetlenmiştir.

Bununla birlikte çok sayıda araştırmada olası farklı teoriler ve modeller önerilmiş, yeni sahalarda yapılan sosyal pazarlama uygulamalarında gelenekselin dışına çıkılmıştır. Yine belirli sağlık davranışlarına odaklanan sosyal pazarlama projeleri araştırma bulgularına ve deneyimlerine dayanarak kendi modellerini geliştirmiştir (Lefebvre, 2000; Luca ve Suggs, 2013).

Sağlık müdahaleleri üzerine yapılan sosyal pazarlama çalışmalarını sistematik olarak inceleyen Luca ve Suggs (2013), s1kça başvurulan teori ve modellerden başka sosyal ă̆ teorsinin, sosyal öğrenme teorisinin, bilgi motivasyon ve davranışsal yetenekler modelinin ayırca bilgi işleme teorisinin kullanıldığını aktarmaktadır. Araştırmacılar teori ve modellerin kullanım yerleri olarak hedef kitle segmentasyonu, kampanya tasarımı, mesaj tasarımı, promosyon ve değerlendirme faaliyetlerini belirtmektedir.

Manikam ve Russell-Bennett (2016) aile içi şiddeti ve teknoloji bağımlılığını ele alan sosyal pazarlama müdahalelerinde sıkça kullanılan teori ve modeller haricinde suç/risk korkusu algı modelleri, sosyal destek teorisi, başaçıkma teorisi, kişisel iletişim ağı ve $A B C$ çerçevesinin kullanıldığını aktarmaktadır. Yazarlar etkili sosyal pazarlama müdahalelerinde destekleyici teorilerin, temel davranışsal itici güçleri ve tüketici içgörülerini yansıtması gerektiğini ve tasarım sürecinde açıkça kullanılması gerektiğini belirtmektedir. 
Tablo 2: Sosyal Pazarlamada Sıkça Kullanılan Teori ve Modellerin Özetleri

\begin{tabular}{|c|c|c|c|}
\hline Düzey & Teori & Odak Noktası & Temel Kavramlar \\
\hline \multirow{6}{*}{ Bireysel Teoriler } & $\begin{array}{l}\text { Değişim } \\
\text { (Mübadele) } \\
\text { Teorisi }\end{array}$ & $\begin{array}{l}\text { Bireylerin kendileri için önemli } \\
\text { olan bir başka değer karşılığında } \\
\text { sahip oldukları bir değerden } \\
\text { vazgeçmeye meyilli olmaları }\end{array}$ & $\begin{array}{l}\text { Ekonomide değiş-tokuş } \\
\text { Tüketici davranışı } \\
\text { Tüketici değeri } \\
\text { Tüketicinin faydası } \\
\text { Tüketici için oluşan maliyetler }\end{array}$ \\
\hline & $\begin{array}{l}\text { Gerekçeli } \\
\text { Eylem Teorisi } \\
\text { ve } \\
\text { Planlı } \\
\text { Davranış } \\
\text { Teorisi }\end{array}$ & $\begin{array}{l}\text { Bireylerin bir davranışa yönelik } \\
\text { tutumları, normlara yönelik algıları } \\
\text { ve değişimin kolaylığına ya da } \\
\text { zorluğuna yönelik algıları }\end{array}$ & $\begin{array}{l}\text { Davranışsal niyet } \\
\text { Tutum } \\
\text { Öznel norm } \\
\text { Algılanan davranışsal kontrol }\end{array}$ \\
\hline & $\begin{array}{l}\text { Sağlık İnanç } \\
\text { Modeli }\end{array}$ & $\begin{array}{l}\text { Kişilerin bir sağlık sorununa } \\
\text { yönelik tehdit algıları, bu } \\
\text { tehlikeden kaçınmanın sağlayacağı } \\
\text { faydalar ve davranışa yönelik kararı } \\
\text { etkileyen faktörler }\end{array}$ & $\begin{array}{l}\text { Algılanan duyarlılık } \\
\text { Alg1lanan ciddiyet } \\
\text { Alg1lanan yararlar } \\
\text { Algılanan engeller } \\
\text { Eylem ipuçları } \\
\text { Özyeterlik }\end{array}$ \\
\hline & $\begin{array}{l}\text { Transteorik } \\
\text { Model }\end{array}$ & $\begin{array}{l}\text { Kişilerin problemli bir davranışı } \\
\text { değiştirmeye yönelik } \\
\text { motivasyonları ve hazır } \\
\text { bulunuşlukları }\end{array}$ & $\begin{array}{l}\text { Değişim aşamaları } \\
\text { Değişim süreçleri } \\
\text { Karar dengesi } \\
\text { Öz yeterlik }\end{array}$ \\
\hline & $\begin{array}{l}\text { Önleyici } \\
\text { (Davranış) } \\
\text { Benimseme } \\
\text { Süreç Modeli }\end{array}$ & $\begin{array}{l}\text { Kişilerin farkındalıklarının } \\
\text { olmadığı aşamadan eylemi } \\
\text { sürdürmeye kadar geçen yolculuğu }\end{array}$ & $\begin{array}{l}\text { Sorunun farkında olmama } \\
\text { Sorunu önemsememe } \\
\text { Eylem hakkında düşünme } \\
\text { Eylemi yerine getirmemeye karar } \\
\text { verme } \\
\text { Eylemi yerine getirmeye karar } \\
\text { verme } \\
\text { Eylemi sürdürme }\end{array}$ \\
\hline & $\begin{array}{l}\text { Korunmaya } \\
\text { Güdülenme } \\
\text { Teorisi }\end{array}$ & $\begin{array}{l}\text { Bilgi kaynaklarının, özellikle de } \\
\text { önceki davranışsal deneyimin } \\
\text { bilişsel değerlendirmeleri teşvik } \\
\text { etmesi ve bunun da koruma } \\
\text { motivasyonunu ortaya çıkarması }\end{array}$ & $\begin{array}{l}\text { Tepki yeterliği } \\
\text { Öz yeterlik } \\
\text { Tehdit ve başa çıkma } \\
\text { Uyumsuz başa çıkma }\end{array}$ \\
\hline $\begin{array}{l}\text { Bireylerarası } \\
\text { Teoriler }\end{array}$ & $\begin{array}{l}\text { Sosyal Bilişsel } \\
\text { Teori }\end{array}$ & $\begin{array}{l}\text { İnsan davranışları, kişisel faktörler, } \\
\text { çevresel faktörler ve bunların } \\
\text { birbirleri ile etkileşimi }\end{array}$ & $\begin{array}{l}\text { Davranışın psikolojik belirleyicileri } \\
\text { Model alarak öğrenme } \\
\text { Davranışın çevresel belirleyicileri } \\
\text { Öz kontrol } \\
\text { Ahlaki geri çekilme }\end{array}$ \\
\hline \multirow{2}{*}{$\begin{array}{l}\text { Toplumsal } \\
\text { Teoriler }\end{array}$} & $\begin{array}{l}\text { Yeniliklerin } \\
\text { Yayılması } \\
\text { Teorisi }\end{array}$ & $\begin{array}{l}\text { Yeni fikir, ürün ya da } \\
\text { uygulamaların bir toplum içinde ya } \\
\text { da bir toplumdan diğerine nasıl } \\
\text { yayıldığ }\end{array}$ & $\begin{array}{l}\text { Yenilik } \\
\text { İletişim kanalları } \\
\text { Sosyal sistem } \\
\text { Zaman }\end{array}$ \\
\hline & $\begin{array}{l}\text { Topluluk } \\
\text { Örgütleme ve } \\
\text { Diğer } \\
\text { Katılımcı } \\
\text { Modeller } \\
\end{array}$ & $\begin{array}{l}\text { Sağlık ve sosyal sorunların } \\
\text { çözümünde topluluk temelli } \\
\text { yaklaşımlar }\end{array}$ & $\begin{array}{l}\text { Aşama teorisi } \\
\text { Örgütsel gelişim teorisi } \\
\text { Örgütlerarası ilişki teorisi } \\
\text { Toplum koalisyonu }\end{array}$ \\
\hline Yönetsel Teoriler & Paydaş Teorisi & $\begin{array}{l}\text { Bir firmanın ya da kurumun } \\
\text { faaliyetlerini etkileyen ya da ilgili } \\
\text { faaliyetlerden etkilenen taraflarla } \\
\text { etkileşim, ortaklık, işbirliği ve } \\
\text { dayanışma }\end{array}$ & $\begin{array}{l}\text { Bir araya getirme } \\
\text { Fonlama } \\
\text { Yaygınlaştırma } \\
\text { Farkındalık yaratma } \\
\text { Sürdürebilirlik } \\
\text { Performans geliştirme }\end{array}$ \\
\hline
\end{tabular}

Kaynak: Özata ve Kapusuz, 2019:74’ten geliştirilmiştir. 


\section{SOSYAL PAZARLAMA KARMASINDA TEORİ KULLANIMI}

Sosyal pazarlamanın hedefi olan sosyal değişim karmaşık ve kapsamlı bir süreci kapsamakta, bu nedenle de onlarca teori ve model arasından seçim yapma imkânı bulunmaktadır. Yayınlanmış çalışmalarda bireysel davranış teorilerine çok fazla dikkat gösterildiği anlaşılmaktadır. Sosyal pazarlama kişisel davranış değişimi stratejilerine bir alternatif olmamakla birlikte, hedef kitle içerişinde istenilen davranışın yaygınlaşması için kullanılabilecek bir araçtır (Lefebvre vd., 1995). Sosyal pazarlamacılar günümüzün hızla değişen koşulları çerçevesinde bilgi birikimlerini ve farklı teorik çerçeve kullanımlarını genişletmek durumundadır. Winett (1995) sosyal pazarlama bileşenlerini davranış teorileri ile entegre eden bir yaklaşım önermiştir. Araştırmacı, 4P üzerine çalışılırken her bir bileşen için çeşitli teorilerin kullanımının mümkün olabileceğini söylemiş ve bu kapsamda öneriler getirmiştir. Yazarın 4P için önerdiği teorilerin özellikle paydaş teorisi, motivasyon teorileri, business to business (B2B) pazarlama modeli ve ekoloji disiplini (bkz. Brennan vd., 2015) ile desteklenerek sosyal pazarlamada 8P (Menegaki, 2012) için genişletilmesi mümkündür (Tablo 3).

Tablo 3: Sosyal Pazarlama Karmasında Önerilen Teoriler

\begin{tabular}{|c|c|}
\hline Değişken & Teori \\
\hline Ürün: Teklif (Sosyal fayda amaçlı aktivasyon) & $\begin{array}{l}\text { Yeniliğin Yayılması Teorisi } \\
\text { Değişim Aşamaları Modeli (Transteorik Model) }\end{array}$ \\
\hline $\begin{array}{l}\text { Fiyat: İlişki/Ortak eylem maliyeti (zaman, çaba, } \\
\text { psikolojik bariyer ve rahatsızlık açısından) }\end{array}$ & $\begin{array}{l}\text { Davranış Analizleri } \\
\text { Sosyal Bilişsel Kuram }\end{array}$ \\
\hline $\begin{array}{l}\text { Tutundurma: Sosyal iletişim, güven inşası için } \\
\text { görünür ve ölçülebilir sonuçlar (Bir belediye } \\
\text { başkanının mektubu, yerel basının kullanımı, sosyal } \\
\text { medya hesapları, SMS mesajları gibi uygulamalar) }\end{array}$ & $\begin{array}{l}\text { Motivasyon Teorileri (mesaj tasarımının } \\
\text { desteklenmesi için) } \\
\text { Sosyal Ağ Teorisi (mesajın yaygınlaştırılmasının } \\
\text { desteklenmesi için) } \\
\text { Gerekçelendirilmiş Eylem Teorisi } \\
\text { Sağlık İnançları Modeli } \\
\text { Korunmaya Güdülenme Kuramı } \\
\text { Sosyal Öğrenme Kuramı } \\
\text { Davranış Analizleri }\end{array}$ \\
\hline $\begin{array}{l}\text { Dağıtım: Bilgi ve eğitim için tüketiciye ulaşılan } \\
\text { kanallar; uygulamanın yapılacağı sosyal müdahale } \\
\text { konuları. }\end{array}$ & $\begin{array}{l}\text { Ekoloji, kamu sağlığı, kamu güvenliği, eğitim, sosyal } \\
\text { dayanışma. }\end{array}$ \\
\hline $\begin{array}{l}\text { 5.Kamuoyu: Hedef kitle, ikincil hedef kitle, politika } \\
\text { yapıcılar, sosyal ağlar, vatandaş katılımı, kulaktan } \\
\text { kulağa iletişim, ünlülerin, politikacıların desteği, odak } \\
\text { gruplar ve ortak analizler }\end{array}$ & $\begin{array}{l}\text { Motivasyon Teorileri } \\
\text { Davranış Analizleri } \\
\text { Ekoloji } \\
\text { Sosyal Bilişsel Kuram } \\
\text { Paydaş Teorisi } \\
\text { Gerekçelendirilmiş Eylem Teorisi } \\
\text { Sağlık İnançları Modeli } \\
\text { Korunmaya Güdülenme Kuramı } \\
\text { Sosyal Öğgrenme Kuramı }\end{array}$ \\
\hline $\begin{array}{l}\text { 6.Ortaklıklar: Başarılı iş adamlarını, devleti, yerel } \\
\text { yönetimleri ve üniversiteleri davet etme. }\end{array}$ & $\begin{array}{l}\text { Paydaş Teorisi } \\
\text { Organizasyonel Gelişim Modeli } \\
\text { B2B Pazarlama Modeli }\end{array}$ \\
\hline $\begin{array}{l}\text { 7.Politika: Mevzuat ve kurumsal çerçeve, bilgiye ve } \\
\text { desteğe erişim. }\end{array}$ & $\begin{array}{l}\text { Politik Teoriler } \\
\text { Gündem Oluşturma Araştırmaları }\end{array}$ \\
\hline $\begin{array}{l}\text { 8.Para kontrolü: Fonlar destekler, bağışlar ve satın } \\
\text { alma gönüllüğünden gelecektir. }\end{array}$ & $\begin{array}{l}\text { Değişim Teorisi } \\
\text { Paydaş Teorisi }\end{array}$ \\
\hline
\end{tabular}

Teori kullanımı, sosyal mühadale tasarımının uygulanması ve sonuçlarının ölçümüyle birlikte sosyal pazarlama karmasının tüm elemanları için bir kavrayış sunmaktaysa da, araştırmacıların teoriyi en çok kullandıkları alan tutundurma çalışmalarıdır (Winett, 1995; Luca ve Suggs, 2013). Sosyal pazarlama müdahalelerinde teori kullanımı, belirli bir davranışın kurallar çerçevesinde mi, öz yeterlilikle mi, çevresel mi, tutumla bağlantılı mı, farklı sosyal sebeplerle mi ya da tüm bunların kombinasyonuyla mı ortaya çıtığını tanımlamak hususunda pazarlamacılara yardımcı olmalıdır (Fishbein ve Yzer, 2003). Daha sonra da bu belirleyiciler sosyal pazarlama karmasının tasarlanmasında kullanılmalıdır (Luca ve Suggs, 2013).

Pazarlama karması bileşenlerinin davranış teorileri ile desteklenmesi, son dönemde sosyal müdahalelerin etkililiği çerçevesinde çokça eleştirilen sosyal pazarlama uygulamalarının teorik bağlamdan uzak bir durum 
arz etmesine güçlü bir cevap üretecektir. İlgili bileşenlerin planlama aşamasında en uygun teorilerle desteklenmesi sonucunda daha etkili sosyal müdahale programlarının ortaya konulması mümkün olacaktır.

\section{SONUÇ}

Sosyal pazarlama programları hedef kitlenin tanımlanmasını, onlara nasıl ulaşılacağını ve tutumlarının belirlenmesini içeren betimleyici araştırma ile uygulama ve değerlendirme süreçlerinden oluşmaktadır. Sosyal pazarlamacıların her üç süreçte de teori ve modellerden faydalanarak sosyal pazarlama çalışmalarının etkililiğini arttırabildikleri görülmektedir (Buyucek vd., 2016; Luca ve Suggs, 2013). Leferbve (2000), bilgi ve deneyimi yüksek olan sosyal pazarlamacıların hangi problemin üstesinden gelineceği, kitleleri nasıl bölümlere ayıracakları, hangi program hedeflerinin olması gerektiği, hangi hedef kitleleri seçecekleri ve bunların nasıl karakterize edileceği, biçimlendirici araştırma faaliyetlerinde hangi soruların sorulacağı, program stratejileri ve taktiklerinin nasıl geliştirileceği, hangilerinin seçileceği, bunların nasıl test edileceği, uygulama/katılım sürecinin nasıl organize edileceği ve yönetileceği, hangi mesajın hedef kitlede yank1 uyandırabileceği, hangi faydalara ve engellere en çok dikkat edilmesi gerektiği, mesajların, ürünlerin ve hizmetlerin en iyi nasıl tanıtılabileceği gibi sorulara doğru cevaplar verebilmek için "teoriler" üzerine çalıştıklarını belirtir.

Sosyal pazarlamacıların teori ve modeller konusundaki geniş bilgi ve seçenekleri onların daha başarılı çalışmalar yapmasına destek verir. Örneğin bir sosyal pazarlamacı betimleyici araştırmalar esnasında bireylerin davranışının temellerini anlamak açısından değişim (mübadele) teorisini (Hastings ve Saren, 2003; Kotler ve Roberto, 1989) kullanabilir. Bununla birlikte insanların davranışlarında etkili olan sosyal faktörlerle çevre faktörlerini göz önüne alarak aynı zamada sosyal bilişsel teori ile sosyal öğrenme teorisinden faydalanabilir (Hastings, 2003). Yine hedef kitleyi tespit ve haritalama için davranış değişim basamakları modelini kullanabilir (Çoknaz vd., 2016). Uygulama aşamasında ise davranış değişikliğine yol açması beklenen "fikri" yaymak ve benimsetmek amaciyla yeniliklerin yayılması modelini kullanabilir. Uygulama esnasında etkiyi büyütmek için paydaş teorisini kullanarak olası paydaşları tanımlayıp koordinasyonlarını arttırabilir (Buyucek vd., 2016). Ortaya çıkan davranışları tanımlamak ve nedenlerini açıklamak için değerlendirme aşamasında davranış değişimi teorisinden faydalanabilir (Thackeray ve Neiger, 2000), süreç değerlendirmeleri için paydaş teorisini kullanabilir (Hodgkins vd., 2019). Bununla birlikte sosyal pazarlamacılar örneğin sadece $\mathrm{ABC}$ çerçevesini kullanarak bir program tasarlayabilir ve uygulayabilir (örn. Manikam ve Russell-Bennett., 2016). Ya da program hedeflerine bağlı olarak planlı davranış teorisi ve teknoloji kabul modelini kapsayacak şekilde iki farklı modelden faydalanabilir (örn. Tweneboah-Koduah vd., 2019). Hangi teori ya da modelin nerede ve ne kapsamda kullanılacağ 1 sosyal pazarlamacının öznel değerlendirmelerine bağlı olarak belirlenecektir.

Görüldüğü üzere sosyal pazarlamacıların sosyal müdahalelerini tasarlarken, uygularken ve değerlendirirken kullanabilecekleri pek çok teori ve model seçeneği mevcuttur. Ancak bu faydalanma çabası öncelikle teori ve model arasındaki ayrımın bilinmesiyle başlamalıdır (Lefebvre, 2000). Daha sonra sosyal pazarlamacılar hedefleri çerçevesinde kullanabilecekleri teori ve modelleri tespit ederek bunlara ilişkin literatüre ve uygulamalara hakim olmalıdır. Özellikle teori ile sosyal müdahalenin entegrasyonu için ortaya konan literatürü incelemeli ve sonuçlar çıkarmalıdır. Entegrasyon konusuna da hakim olan sosyal pazarlamacı artık bir ya da birden çok teori ya da model desteğiyle sosyal müdahale tasarımı yapabilir, uygulama ve değerlendirme süreçlerini çok daha sağlıklı bir biçimde yürütebilir.

Türkiye'de yapılan sosyal pazarlama çalışmalarında teori ve model kullanımının sıklığı, kapsamı ile hangi sosyal müdahaleler için hangi teori ve modellerin tercih edildiği henüz araştırılmamıştır. Ayrıca bir sosyal müdahale ile bir teori ya da modelin birbirine nasıl entegre edileceğini ele alan çalışmalara henüz rastlanmamıştır. Söz konusu nedenlerle Türkiye'deki sosyal pazarlamacılar için teori ve model kullanımı henüz yeni bir çalışma sahasıdır. Bu çalışmada ele alınan konular ve incelenen araştırmalar çerçevesinde derlenen bilgilerin Türkiye'deki sosyal pazarlama çalışmalarında teori ve model kullanımı için önemli bir başlangıç teşkil edeceği düşünülmektedir. 


\section{KAYNAKLAR}

Ajzen, I., 1985. From intentions to actions: A theory of planned behavior. In J. Kuhl \& J. Beckman (Eds.), Action Control, From Cognition to Behaviour, Springer-Verlag Berlin Heidelberg, 11-39.

Andreasen, A. R. 1995. Marketing Social Change San Francisco: Jossey-Bass Publishers.

Andreasen, A. R. 1997. Challenges for the science and practice of social marketing. In M. E. Goldberg, M. Fishbein, \& S. E. Middlestadt (Eds.), Social marketing: Theoretical and practical perspectives. Mahwah, NJ: Lawrence Erlbaum Associates.

Andreasen, A.R., 2006. Social Marketing in the 21st Century. Sage Publications Ltd, California.

Apay, A. 2007. Yetişkinlerin tedbirsiz davranmasını belirleyen etkenlerin incelenmesi. Ankara Üniversitesi Eğitim Bilimleri Enstitüsü Yayınlanmamış Doktora Tezi, Ankara.

Baranowski, T., Cheryl L. P. and Guy S. P. 1997. Social cognitive theory in health behavior and health education (2nd ed), Karen Glanz, F.M. Lewis and B.K. Rimer, eds, San Francisco: Jossey-Bass Publishers, 153-178.

Berkowitz, J. M., Huhman, M., Heitzler, C. D., Potter, L. D., Nolin, M. J., and Banspach, S. W. 2008. Overview of formative, process, and outcome evaluation methods used in the VERBTM Campaign. American Journal of Preventive Medicine, 34(6 Suppl), S222-S229.

Bickman, L. 1972. Environmental attitudes and actions. Journal of Social Psychology, 87, 323-324.

Brennan L., Fry, M., Previte. J. 2015. Strengthening social marketing research: Harnessing “insight” through ethnography Australasian Marketing Journal 23, pp. 286-293.

Buchanan, D.R., Reddy, S., and Hossain, Z. 1994. Social marketing: A critical appraisal, Health Promotion International 9(1): 49-57. Hastings G. and Saren M. 2003. The critical contribution of social marketing Theory and application. Marketing Theory. Volume 3(3): 305-322 içinde.

Buyucek, N., Kubacki, K., Rundle-Thiele S., Bo Pang. 2016. A systematic review of stakeholder involvement in social marketing interventions. Australasian Marketing Journal 24, pp:8-19.

Coll, R. K. 2006. The role of models, mental models and analogies in chemistry teaching. In P. J. Aubusson, A. G. Harrison \& S. M. Ritchie (Eds.), Metaphor and analogy in science education (Vol. 30, pp. 65-77). Printed in the Netherlands.: Springer.

Collette, A. T., \& Chiappetta, E. L. 1984. Science instruction in the middle and secondary schools. columbus: Merrill Publishing Company. Çelik, S. 2015. Fen bilgisi öğretmen adaylarının bilimsel modeller ile ilgili anlayışları. EÜFBED - Fen Bilimleri Enstitüsü Dergisi Cilt-Sayı: 8-1, 9-26 içinde.

Çelik, S. 2015. Fen bilgisi öğretmen adaylarının bilimsel modeller ile ilgili anlayışları. EÜFBED - Fen Bilimleri Enstitüsü Dergisi Cilt-Say1: 8-1, 9-26.

Çoknaz D., Özbakır Umut M., Nurtanış Velioğlu M. 2016. sosyal pazarlamada hazır kitleyi bulmak ve haritalamak: baby boomers'larda fiziksel aktiviteye yönelik araştırma. Eskişehir Osmangazi Üniversitesi Sosyal Bilimler Dergisi Aralık, 17(2), 81-105.

D’Onofrio, C. N. 1992. Theory and the empowerment of health education practitioners. Health Education Quarterly, 19, pp.385-403.

Donovan, J. R., and Henley, N. 2003. Social marketing: Principles and practice. Melbourne, Australia: IP Communications. McKie, D. and Toledano, M. 2008. Dangerous liaison or perfect match? Public relations and social marketing. Public Relations Review 34 (2008) 318-324 içinde.

Fishbein M, ve Ajzen, I., 1975. belief, attitude, intention and behavior, an introduction to theory and research. Reading, MA: Addison-Wesley.

Fishbein, M., and Yzer, M. C. (2003). Using theory to design effective health behavior interventions. Communication Theory, 32, 164-183.

Freeman, R.E., 1984. Stakeholder management: Framework and philosophy. Pitman, Boston.

Geller, E. S. 1981. Evaluating energy conservation programs: Is verbal report enough? Journal of Consumer Research, Vol.8, December 1981, 331-335.

Geller, E. S., Erickson, J. B. and Buttram, B. A. 1983. Attempts to promote residential water conservation with educational, behavioral and engineering strategies. Population and Environment Behavioral and Social Issues, 6 , 96-112.

Glanz, Karen, Frances Marcus Lewis and Barbara K. Rimer, eds. 1997. Health Behavior and Health Education (2nd ed). San Francisco: Jossey-Bass Publishers.

Glanz, K. ve Rimer, B.K. 2005. Theory at a glance: A guide for health promotion practice (2nd Edition). National Cancer Institute (US). Washington, DC: NIH.

Green, L.W., Glanz K, Hochbaum G, 1994. Can we build on, or must we replace, the theories and models in health education? Health Education Research 9: 397-404.

Hastings, G. 2003. Relational paradigms in social marketing. Journal of Macromarketing, Vol. 23 No. 1, June 6-15 DOI: $10.1177 / 0276146703252488$

Hastings G. and Saren M. 2003. The critical contribution of social marketing Theory and application. Marketing Theory. Volume 3(3): 305-322.

Hodgkins S., Rundle-Thiele, S., Knox, K., Kim, J. 2019. Utilising stakeholder theory for social marketing process evaluation in a food waste context. Journal of Social Marketing. Vol. 9 No. 3, pp. 270-287. 
Housten, F.S. and Gassenheimer, J.B. 1987. Marketing and Exchange. Journal of Marketing 51: 3-18.

Huhman, M. E., Potter, L. D., Duke, J. C., Judkins, D. R., Heitzler, C. D., and Wong, F. L. 2007. Evaluation of a national physical activity intervention for children: VERBTM Campaign, 2002-2004. American Journal of Preventive Medicine, 32(1), 38-43.

Kocagöz, E. ve Dursun, Y. 2010. Algılanan davranışsal kontrol, Ajzen'in teorisinde nasıl konumlanır? Alternatif model analizleri. KMÜ Sosyal ve Ekonomik Araştırmalar Dergisi 12 (19) 139-152.

Kotler, P. and Zaltman, G. 1971. Social marketing: an approach to planned social change, Journal of Marketing, Vol. 35, July, 3-12.

Kotler, Phillip and Eduardo L. Roberto. 1989. Social marketing: strategies for changing public behavior. New York: The Free Press.

Kotler, P. 2000. Marketing management (Millennium Edition). Upper Saddle River, NJ: Prentice Hall International.

Kotler, P., Kartajaya H. and Setiawan I. 2010. Marketing 3.0. John Wiley and Sonz, Inc.

Lefebvre, R. Craig, Deborah Lurie, Laura Saunders Goodman, Linda Weinberg and Kathleen Loughrey 1995. Social marketing and nutrition education: Inappropriate or misunderstood?" Journal of Nutrition Education 27 (3), 146 150.

Lefebvre, R.C., Carol Olander and Elyse Levine 1999. The 1mpact of multiple channel delivery of nutrition messages on student knowledge, motivation and behavior: results from the team nutrition pilot study. Social Marketing Quarterly 5(3), 90-98.

Lefebvre, R. C. 2000. In PN Bloom \& GT Gundlach (Eds.), Handbook of Marketing and Society, Newbury Park, CA: Sage Publications.

Luca, N. R. and Suggs, L. S. 2013. Theory and model use in social marketing health interventions, Journal of Health Communication, 18:1, 20-40, DOI:10.1080/10810730.2012.688243.

MacFadyen, L., Stead, M., \& Hastings, G., 1999. Synopsis of social marketing. Retrieved June 4, 2005, from: http://www.ism.stir.ac.uk/pdf docs/socialmarketing.pdf. McKie, D. and Toledano, M. 2008. Dangerous liaison or perfect match? Public relations and social marketing. Public Relations Review 34 (2008) 318-324 içinde.

Maibach, E.W. and Cotton, D. 1995. Moving people to behaviour change: A staged social cognitive approach to message design. In E. Maibach and R.L. Parrott (eds) Designing Health Messages. Approaches From Communication Theory and Public Health Practice, pp 41-64. Newbury Park, CA: Sage Publications.

Manstead, A. S. R., 2001. Attitudes and behavior, In N. J. Smelser \& P. B. Baltes (Eds.), International Encyclopedia of the Social and Behavioral Sciences, Oxford: Pergamon, 909-913. Kocagöz, E. ve Dursun, Y. 2010. Alg1lanan davranışsal kontrol, Ajzen'in teorisinde nasıl konumlanır? Alternatif model analizleri. KMÜ Sosyal ve Ekonomik Araştırmalar Dergisi 12 (19) 139-152 içinde.

Marcus, Bess H., Stephen W. Banspach, R. Craig Lefebvre, Joseph S. Rossi, Richard A. Carleton and David b. Abrams. 1992. Using the stages of change model to increase the adoption of physical activity among community participants. American Journal of Health Promotion, 6 (6), 424-429.

McKie, D. and Toledano, M. 2008. Dangerous liaison or perfect match? Public relations and social marketing. Public Relations Review 34 (2008) 318-324.

Menegaki, A.N., 2012. A social marketing mix for renewable energy in Europe based on consumer stated preference surveys, Renewable Energy, Vol: 39, pp: 30-39.

Montano, Daniel E., Kasprzyk, D. and Taplin, S. H. 1997. The theory of reasoned action and the theory of planned behavior," in Health Behavior and Health Education (2nd ed), Karen Glanz, F.M. Lewis and B.K. Rimer, eds, San Francisco: Jossey-Bass Publishers, 85-112.

Nalbantoglu, A. 2018. Current problems and applications in marketing ethics. Journal of Social and Humanities Sciences Research (JSHSR). Vol:5 Issue:30 pp:4249-4264.

Neuwirth, K., Dunwoody, S. and Griffin, R.J. 2000. Protection Motivation and Risk Communication. Risk Analysis, 20 (5), 721-734. Apay, A. 2007. Yetişkinlerin tedbirsiz davranmasını belirleyen etkenlerin incelenmesi. Ankara Üniversitesi Eğitim Bilimleri Enstitüsü Yayınlanmamış Doktora Tezi, Ankara içinde.

Novelli, W. D. 1990, “Applying Social Marketing to Health Promotion and Disease Prevention,” in Health Behavior and Health Education, Karen Glanz, F.M. Lewis and B.K. Rimer, eds, San Francisco: Jossey-Bass Publishers, 342369.

Oh, P. S., and Oh, S. J. 2011. What teachers of science need to know about models: An overview. International Journal of Science Education, 33(8), 1109-1130. Çelik, S. 2015. Fen bilgisi öğretmen adaylarının bilimsel modeller ile ilgili anlayışları. EÜFBED - Fen Bilimleri Enstitüsü Dergisi Cilt-Sayı: 8-1, 9-26 içinde.

Oldenburg, Brian, Deborah M. Hardcastle and Gerjo Kok. 1997. Diffusion of Innovations. In Health Behavior and Health Education(2nd ed), Karen Glanz, F.M. Lewis and B.K. Rimer, eds, San Francisco: Jossey-Bass Publishers, 270286.

omer-demir.net/sosyalbilimlersozlugu/degisim-kurami/(Erişim tarihi: 16.08.2020)

www.orau.gov (Erişim tarihi: 25.08.2020)

Özata, F. Z. ve Kapusuz, S. 2019. Aşı kararsızlı̆̆1 ve aşı reddi konusuna sosyal pazarlama bakış açısından çözüm önerileri. Anadolu Üniversitesi İktisadi ve İdari Bilimler Fakültesi Dergisi. Cilt/Vol: 20 - Say1/No: 1, sf:65-83.

Price, S. M., Huhman, M., \& Potter, L. D. 2008. Influencing the parents of children aged 9-13 years: Findings from the VERBTM Campaign. American Journal of Preventive Medicine, 34(6 Suppl 1), S267-S274. 
Prochaska, James O. and Wayne F. Velicer. 1997. The transtheoretical model of health behavior change. American Journal of Health Promotion, 12 (1), 38-48.

Rippetoe, P.A. and Rogers, R.W. 1987. Effects of components of protection motivation theory on adaptiveand maladaptive coping with a health threat. Journal of Personality and Social Psychology,3, 596-604.

Rogers, Everett M. 1983. Diffusion of Innovations. New York: The Free Press.

Rogers, R.W. 1975. A protection motivation theory of fear appeals and attitude change. The Journal ofPsychology,91, 93-114.

Rogers, R.W. 1983. Cognitive and physiological processes in fear appeals and attitude change: a revisedtheory of protection motivation. In: Caicioppo, B.L., Petty, L.L. and Shapiro, D. (Eds.),SocialPsychophysiology:A Source Book, pp. 153-176. Guilford, London.

Shamini Manikam and Rebekah Russell-Bennett. 2016. The social marketing theory-based (SMT) approach for designing interventions. Journal of Social Marketing Vol. 6 No. 1, pp. 18-40. DOI 10.1108/JSOCM-10-2014-0078

Sutton, Sharyn M., George I. Balch and R. Craig Lefebvre. 1995. Strategic questions for consumer-based health communication, Public Health Reports, 9, 725-733.

Thackeray, Rosemary and Neiger, Brad L. 2000. Establishing a relationship between behavior change theory and social marketing: implications for health education, Journal of Health Education, 31:6, 331-335.

Tweneboah-Koduah, E. Y., Adams, M., Acheampong, G. 2019. The role of theories in social marketing in predicting physical activity behavior among the youth. Journal of Social Marketing. Vol. 9 No. 4, pp. 398-417.

Umeh, K.. 2004. Cognitive appraisals, maladaptive coping, and past behaviour in protection motivation, Psychology \& amp; Health, 19:6, 719-735, DOI:10.1080/0887044042000196692

Walsh, Diana Chapman, Rima E. Rudd, Barbara A. Moeykens and Thomas W. Maloney. 1993. Social marketing for public health. Health Affairs, Summer, 104-119.

Winett, Richard A. 1995. A framework for health promotion and disease prevention programs, American Psychologist, 50, 341-350.

Wong, F., Huhman, M., Heitzler, C., Asbury, L., Bretthauer-Mueller, R., McCarthy, S., \& Londe, P. 2004. VERBTMA social marketing campaign to increase physical activity among youth. Preventive Chronic Disease, 1(3), 1-7. 